The University of San Francisco

USF Scholarship: a digital repository@ Gleeson Library |

Geschke Center

\title{
The Visual Image of Chemistry: Perspectives from the History of Art and Science
}

Joachim Schummer

Tami I. Spector

University of San Francisco, spector@usfca.edu

Follow this and additional works at: http://repository.usfca.edu/chem_fac

Part of the Chemistry Commons, and the History of Science, Technology, and Medicine Commons

\section{Recommended Citation}

Joachim Schummer \& Tami I. Spector. The Visual Image of Chemistry: Perspectives from the History of Art and Science. HYLE-International Journal for Philosophy of Chemistry, Vol. 13, No.1 (2007).

This Article is brought to you for free and open access by the Chemistry at USF Scholarship: a digital repository @ Gleeson Library| Geschke Center. It has been accepted for inclusion in Chemistry Faculty Publications by an authorized administrator of USF Scholarship: a digital repository @ Gleeson Library $\mid$ Geschke Center. For more information, please contact repository@usfca.edu. 


\title{
The Visual Image of Chemistry
}

\author{
Perspectives from the History of Art and Science
}

\author{
Joachim Schummer E Tami I. Spector
}

\begin{abstract}
In this paper we investigate the most important visual stereotypes of chemistry as they occur in current portraits of chemists, depictions of chemical plants, and images of chemical glassware and apparatus. By studying the historical origin and development of these stereotypes within the broader context of the history of art and science, and by applying aesthetic and cultural theories, we explore what these images implicitly communicate about the chemical profession to the public. We conclude that chemists, along with commercial artists, have unknowingly created a visual image of chemistry that frequently conveys negative historical associations, ranging from imposture to kitsch. Other elements of this image, however, aestheticize chemistry in a positive manner by referring to classical ideals of beauty and borrowing from revered motifs of modern art.
\end{abstract}

Keywords: public image of chemistry, visual stereotypes, history of art, aesthetics, bistory of science.

\section{Introduction}

When chemists complain about their bad public image they frequently forget that this image has been shaped over many centuries, and that chemists themselves have played an active part in its creation. PR managers know well that the public image of science is created at the interface between science and the public and results from the interaction between scientists and non-scientists. They also appear to understand that visual images are extremely important for carrying a message to the public, otherwise they would not produce such a wealth of picture-laden glossy brochures. Like their clients from chemistry or chemical industry, however, they are less versed in the historically based cultural implications of the visual elements they employ to portray chemistry, in part because scholarly studies on this topic are virtually nonexistent. Although chemistry is routinely portrayed by visual stereotypes, no effort

HYLE - International Journal for Philosophy of Chemistry, Vol. 13 (2007), 3-41. Copyright $(2007$ by HYLE and Joachim Schummer E Tami I. Spector. 
has been made thus far to understand what implicit sociocultural messages they convey. The use of such images without knowledge of their historical contexts, no matter how highly polished, can be embarrassing if, as we show, the stereotypes carry with them negative associations.

In an earlier quantitative study we have analyzed the popular image of science and the visual self-representation of scientists (Schummer \& Spector 2007). Unlike other disciplines, chemistry not only dominates the popular image of science overall, it also stands out for its extremely conservative visual self-representation. Chemists, rather than correcting the popular clichés that they frequently complain about, reinforce these clichés in their own selfrepresentation. In this paper we use the visual material from our earlier study for a complementary qualitative analysis of the most important visual stereotypes of chemistry as they occur in portraits of chemists (Section 2), depictions of chemical plants (Sections 3\&4), and images of chemical glassware and apparatus (Section 4). In order to explore their meaning and visual associations, we delve deeply into our visual culture, which includes the history of science, the history of art, and aesthetics. We investigate the historical origins of these stereotypes, their predecessors, and the cultural contexts in which they emerged and how they have changed over time to assume their current meaning. A historical approach not only has the advantage of tracking the development of these stereotypes, and thus the dynamics of our visual culture, it also reveals their earlier sociocultural associations and connotations which, even if they no longer prevail, are still contained by the images. In addition, examining these visual chemical stereotypes within the broader visual culture allows us to interpret them in the context of past and present aesthetic and cultural frameworks.

\section{The Chemical Portrait: Its Origin and Meaning}

Whenever today's chemists want to be portrayed in such a way that anybody can recognize their professional identity, they usually hold up in their hand a flask filled with some liquid that they visually inspect. ${ }^{1}$ This posture has become the stereotypical visual icon of chemistry in self-portraits, professional photographs, and clip-art cartoons (Figure 1a/b). Some chemists might feel uncomfortable with this pose because it does not accurately embody their daily professional work. They might wonder about the visual conventions that forces them to assume this strange pose or about the historical origin and implications. In this section we investigate the historical origin and development of this motif. We argue that before chemists assumed it as their 
professional icon, the motif, originally representing uroscopy, was first an icon of medicine and then became a symbol of quackery and imposture.
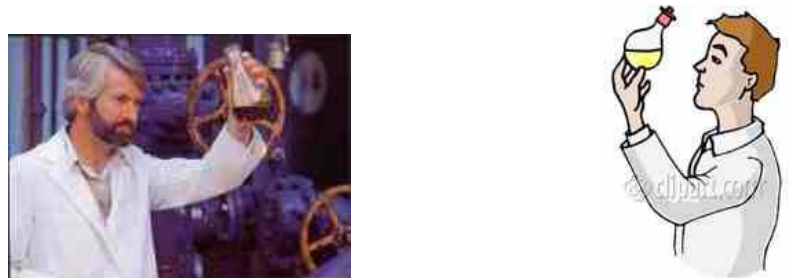

Figure 1. The typical chemical portrait in (a) photographs and (b) clip-art cartoons (from clipart.com).

\subsection{Uroscopy becomes an emblem of medicine}

Along with pulse feeling, ${ }^{2}$ uroscopy (the examination of the patients' urine) was the major means of medical diagnosis in late ancient, medieval, and early modern medicine. Color, smell, taste, and precipitate in fresh urine were supposed to reveal to the learned physician the specific disease and temperament of his patient. Briefly mentioned in the Hippocratic Corpus and extensively dealt with by Galen, the doctrine of uroscopy later became part of the medical core curricula of the newly established Christian universities in Western Europe. This shift of uroscopy into the core curricula of Christian universities was facilitated by the translation of Islamic medical texts from Arabic into Latin and the establishment of the school of Salerno, the first medical school in Europe.

Before this time medicine had been considered a mechanical art or craft, such as carpentry and forging, and excluded from Church school curricula, which had focused on the seven liberal arts and the study of the Bible. Despite this, when medicine did become part of the university curricula, it was quickly accepted as a highly revered discipline. In this setting 'academic physicians' had to distinguish themselves from 'lay' medical practitioners, who continued to provide major medical care for people well into the $18^{\text {th }}$ century. In particular, they distinguished themselves through their knowledge of the nature and causes of diseases and health - hence the English term 'physicke' for medicine up to the $18^{\text {th }}$ century. This knowledge was largely based on Galen's theory of humors, from which the diagnostic capacities of urine as an indicator of humoral imbalance derived. Thus, when it came to the academic physicians choosing an emblematic representation for their field - each of the seven liberal arts had a long established emblem or visual symbol (Lindgren 1992) - they chose the symbol of uroscopy: a man holding up and examining a glass flask filled with urine, a so-called 'matula'. 
Although we still know little about medieval visual culture, there is some evidence for the early development and use of this emblem. Since late antiquity, outside of the Islamic world, illustrations were frequently used in medical texts for entertainment rather than for demonstration (Grape-Albers 1977, Zotter 1980). Typically, written medical recipes and treatments were illustrated by a physician handing over a vessel of medicine to his patient. Because that image strongly resembles the later depictions of uroscopy, where a patient hands over a matula to the physician, it is very likely that this motif is the iconographical origin of the symbol of uroscopy. Moreover, there was a well-developed medieval Christian art of decorating the Bible with colorful miniatures of Bible stories in the margin or within the enlarged first letters of each chapter. That art was also applied to the earliest Latin translations of Arabic and Greek medical texts such as Avicenna's Canon medicinae, the Articella (a digest of Galen), and what was known as the Aphorisms of Hippocrates. In all of these early Latin manuscript translations we find miniatures representing the practice of uroscopy in prominent places (see Figures $2 \mathrm{a}$ and $\mathrm{b})$. $^{3}$

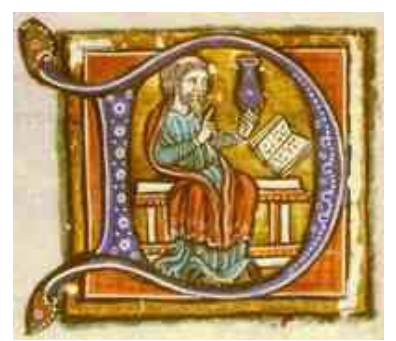

Figure 2a. Illustration from Hunayn ibn Ishaq al-'Ibadi, 809?873 (known as Joannitius).

Isagoge Johannitii in Tegni Galeni. (called Articella), Oxford, 13 th century ms (DeRicci NLM [78], Fol. 42v, National Library of Medicine).

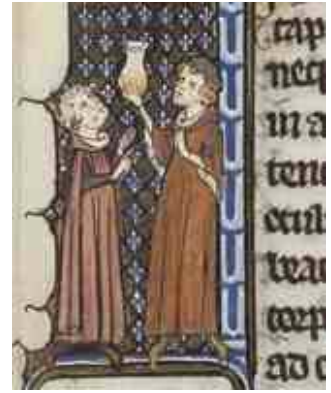

Figure 2b. Illustration from Avicenna, Canon medicinae, trans from Arab by Gerard of Cremona) France; 1283. decoration added c. 13501400 (The Hague, MMW, 10 B 24, fol. 8r, National Library of the Netherlands).

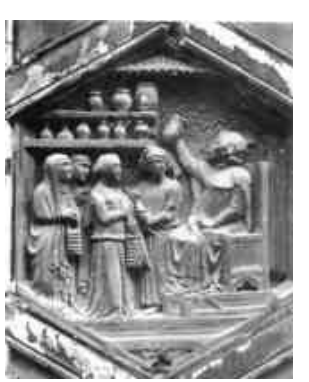

Figure 2c. Relief of medicine by Andrea Pisano (12951348) from 1334-6, after a drawing by Giotto; lower part, close to the allegorical depictions of the seven liberal arts, of Giotto's Campanile at the Cathedral of Florence (repr. from Schadewaldt 1967, p. 105).

Figure 2 shows three depictions of uroscopy from the $13^{\text {th }}$ and $14^{\text {th }}$ centuries that later, with some modifications, became common motifs: the study of uroscopy with matula and book, the teaching of uroscopy to a pupil, and the medical practice of uroscopy, with patients lining up with their boxed matulae in front of a physician. However, in the first two manuscript based images the physician holds the bottom of the matula, which is still reminiscent of the 
late antique motif of the medicine vessel described above. Only the third one (Figure 2c) presents the posture that later became stereotypical for medicine and much later for chemistry: the flask held at the neck and raised high in front of the eyes. Unlike the two medical manuscript illustrations (Figures 2a and b) this relief, which was publicly placed among Giotto's/Pisano's famous emblematic representations of the liberal arts at the Campanile of the Cathedral of Florence, was clearly intended to be a popular emblematic representation of medicine. ${ }^{4}$
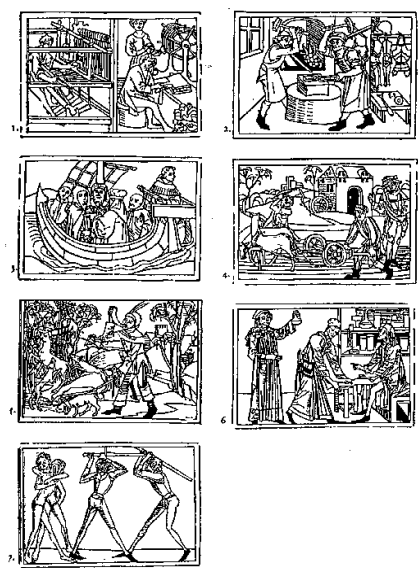

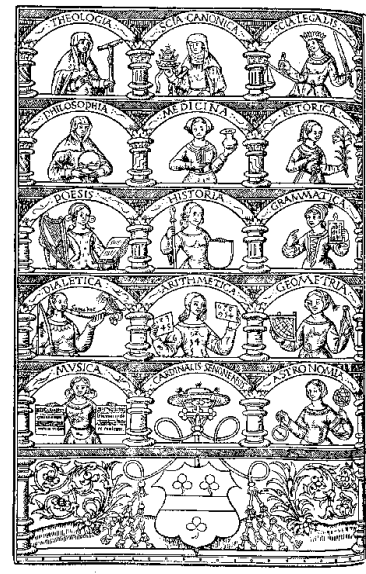

Figure 3b. Emblematic depiction of the 14 arts, from Bartholomeus Chasseuneux: Catalogus gloriae mundi, Lugdunum 1529 (note medicine in the middle of second row) (repr. from Lindgren 1992, p. 67).

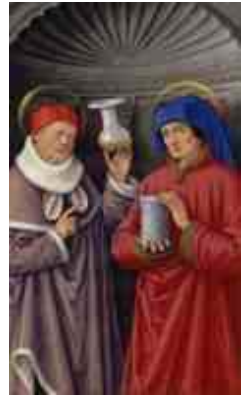

Figure 3c. Cosmas and Damian, the twin saints and Christian patrons of medicine; miniature from "Heures

d'Anne de Bretagne", early 16th century (Bibliothèque Nationale, Paris, Richelieu Manuscripts Latin 9474, Fol. 173v).

Prior to the establishment of European universities a debate had begun about the order of knowledge and thus about the ranking and order of the arts and crafts. This debate continued for centuries and employed emblematic depictions of the various disciplines, which are another useful source for medieval visual studies. In these illustrations medicine was routinely portrayed through uroscopy (Figures $3 \mathrm{a}$ and b). By the late $14^{\text {th }}$ century uroscopy was a fully established public emblem of medicine throughout Europe. The image was probably even used as a trademark of medicine and put on signboards at 
the doors of practicing physicians. ${ }^{5}$ By the early $15^{\text {th }}$ century this symbol was so highly venerated that the twin saints Cosmas and Damian, who had become the Christian patrons of medicine due to a 'miraculous' surgery in the $3^{\text {rd }}$ or $4^{\text {th }}$ century, were often portrayed in the pose of urine inspection in churches and other religious contexts (Figure 3c). ${ }^{6}$

\subsection{Uroscopy becomes a symbol of quackery and fraud}

Medicine has never been without its critics. A widespread early Christian critique involved an argument based on how useless and powerless medicine was compared to the Almighty. In late medieval caricatures, which widely used animals to mock their subjects, the 'physician as ape' or the 'ape as physician' became a popular motif (Janson 1952) (Figure 4a). In the late $15^{\text {th }}$ century, along with the devastating pests in Europe, the skeleton (a symbol of death) began to replace the ape in popularity, resulting in images that portrayed powerless urine inspecting doctors confronted with naked death. A typical example is Holbein's Dance of the Death (Figure 4b).?

Apart from the religious criticisms of medicine, more specific critiques of medical practice with a particular focus on uroscopy grew during the $16^{\text {th }}$ century. People began to mock the increasingly fantastic claims about the diagnostic potential of uroscopy, which by this time had expanded to include Paracelsian methods of urine distillation and quasi-chemical tests. In particular, the notion that the urine-filled matula would somehow map the body of the patient and thus allow localizing diseases, which culminated in Leonhardt Thurneisser's urine distillation apparatus in the shape of a man (Figure 4c), became subject to satire. For instance, Pieter Brueghel the Elder produced a satirical drawing of a doctor and his dog discovering a fanciful humunculus in a matula (Figure 4d). Despite these criticisms the business of uroscopy flourished during this time period and its practitioners were quite well-paid, which further encouraged satirists like Thomas Murner to attack both physicians for their greed and uselessness and uroscopy patients for their foolishness (Figure 4e).

Because vernacular textbooks on uroscopy began to be printed in large numbers in the $16^{\text {th }}$ century, the art of urine inspection and 'pisse prophecy' (uromancy) became extremely popular among patients, inducing a rapid growth of self-educated uroscopists. As a result the medical establishment was challenged to defend their academic prestige by clearly distinguishing themselves from these practitioners. By 1601 the statutes of the College of Physicians of London declared, „It is ridiculous and stupid to attempt to interpret anything definite and certain merely from inspection of the urine and by inference there from, whether about the type and nature of the illness, or the state and condition of the sufferer," to which was later added „for that 
reason we desire and decree that neither any Collegiate nor any candidate should, like the sly imposter, use mere inspection of the urine in his consultation" (Connor 2001). Physicians all over Europe published pamphlets and books, such as Thomas Brian's Pisse-Prophet (London, 1637) and Johan Van Dueren's De Ontdekking der Bedriegeryen Vande gemeene Pis-Besienders (Amsterdam, 1688) (see Figure 4f) to denounce the quackery and fraud of uroscopy practitioners. Of course, physicians continued to practice urine inspection, but, as they were quick to point out, their analysis was based on the knowledge of causes ('physicke') while their competitors relied on the unlearned practice of 'empirical medicine'. By the $17^{\text {th }}$ century the medical establishment had deliberately destroyed the medieval emblem of medicine. Uroscopy was no longer a symbol of learned medicine. The image of a man gazing at a flask in his hand was now a symbol of quackery, imposture, and fraud, and medicine was left without a professional icon. To fill the gap, the medical establishment of that time rediscovered the ancient Greco-Roman symbol of medicine, the Rod of Asclepius, which had been virtually absent in the previous Christian era, and claimed it as their new symbol (Figure $4 \mathrm{~g}$ ). ${ }^{8}$

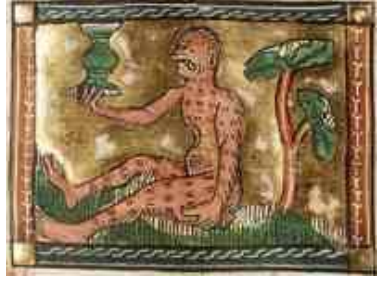

Figure 4a. Jacob van Maerlant: Der Naturen Bloeme, Flanders c. 1350 (KB, KA 16, Folio 69r, National Library of the Netherlands).

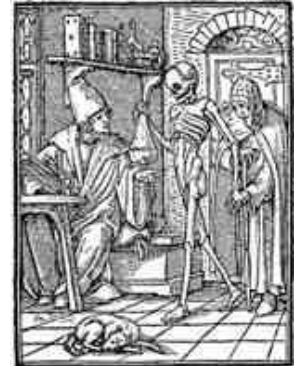

Figure 4b. Hans Holbein: The Dance of Death, Lyons 1538, XXVI. "The Physician" (woodcut) (repr. from Holländer, 1903, p. 283).

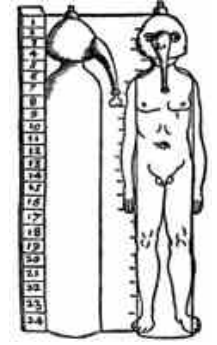

Figure 4c. Urine distillation apparatus from Leonardt Thurneisser (Aurora Thesaurusque Philosophorum Paracelsi, Basel 1577). 


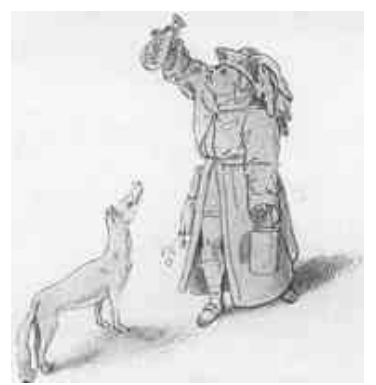

Figure 4d. Pieter Brueghel the Elder (c.1525-1569), detail from a satirical drawing of medicine (repr. from Holländer 1905, p. 52

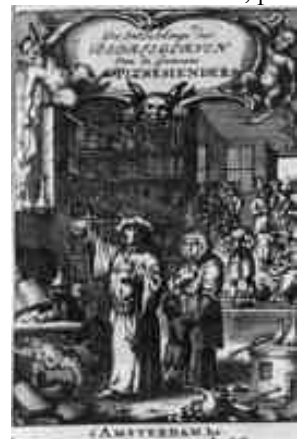

Figure 4f. Frontispiece of Johan Van Dueren: De Ontdekking der Bedriegeryen Vande gemeene PisBesienders, Amsterdam 1688.

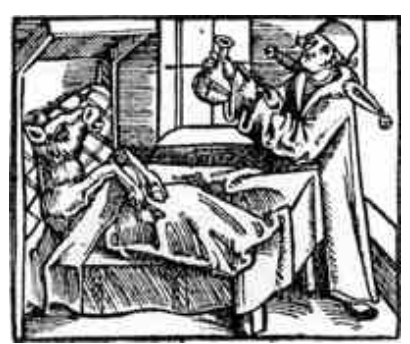

Figure 4e. Thomas Murner: Narrenbeschwörung (1512), "Der Kälberarzt" (The calf doctor) (repr. from Holländer 1905, p. 89)

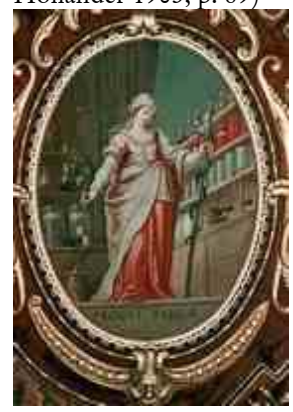

Figure 4g. Peter Candid: "Allegory of Medicine”, 1619-22, fresco in the town hall of Augsburg.

\subsection{From quack medicine to alchemy}

Among generations of $17^{\text {th }}$-century Flemish and Dutch genre painters, who frequently derived from the schools of Rubens and Rembrandt, medical quackery became a favorite topic. Apart from brutal tooth-pullers and stupid surgeons, urine inspection was their most important motif. Since their paintings sold well, Flemish and Dutch genre painters produced an enormous flood of urine inspecting doctors obviously copying each other and themselves hundreds of times. Dozens of paintings of this motif are known, including those of David Teniers the Elder (1582-1649), Adriaen Brouwer (1605-1638), Joos van Craesbeck (1605-1661), Adriaen van Ostade (16101685), David Teniers the Younger (1610-1690), Jan Olis (1610-1676), David Ryckaert the Younger (1612-1661), Gerard Dou (1613-1675), Thomas Wyck (c.1616-1677), Gerard (II) Ter Borch (1617-1681), Matheus Van Helmont (1623-1679), Jan Steen (1626-1679), Samuel van Hoogstraten (1627-1678), 
Gabriel Metsu (1629-1667), Abraham van Dyck (1635-1672), Gilles van Tilborgh (c.1635-c.1678), Frans van Mieris (1635-1681), Jacob van Toorenvliet (c.1635-1719), Godfried Schalcken (1643-1706), Gerard Thomas (16631720), and Balthasar van den Bossche (1681-1715). ${ }^{9}$
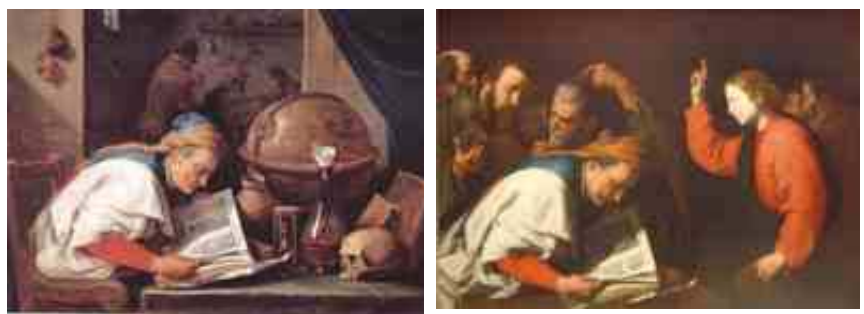

Figure 5a. David Teniers: "The Figure 5b."Jesus and the doctors of the Faith"

Alchemist", oil on wood, 27,5 x 38,5 by the entourage of Giuseppe Ribera (1591-1652),

$\mathrm{cm}$, ca. 1656-60 (Kunsthistorisches

ca. 1630 (Kunsthistorisches Museum Wien).

Museum Wien).
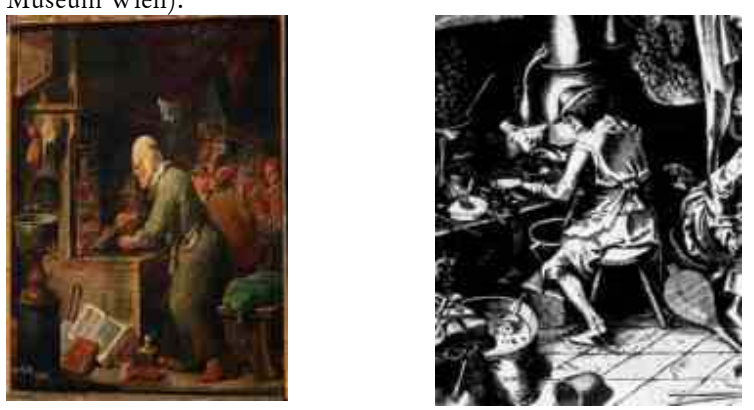

Figure 5d. Pieter Brueghel the Figure 5c. David Teniers: The Al- Figure 5d. Pist
chemist, oil on wood, 47 x $36 \mathrm{~cm}$, ca. Elder (ca. 1525-69): "The 1670 (Madrid, Museo del Prado) Alchemist" (detail); engraving by Philipp Galle, 1558 (Germanisches Nationalmuseum).

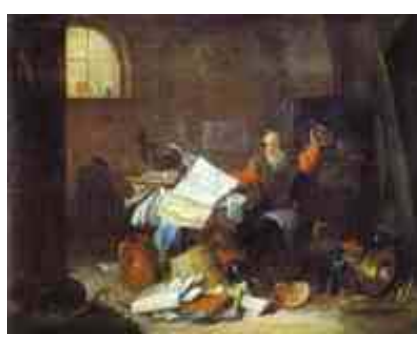

Figure 5g. David Teniers (the

Younger or Elder?): The Alchemist.

Oil on canvas (Palazzo Pitti, Galleria

Palatina, Florence)

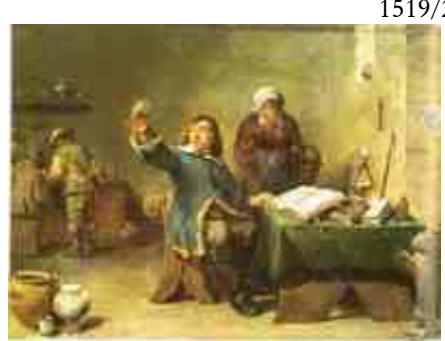

Figure 5h. David Teniers: The Village Doctor, probably c. 1650, (Palais des Beaux-Arts, Brussels)
Figure 5e. Hans Weiditz the Younger (ca. 1485-1536)

Woodcut (detail), printed in the German trans. of Petrarch's De remediis..., Augsburg $1519 / 20$, chapter on alchemy. 
Neither uroscopy nor the general image of a man gazing at a flask in his hand was part of the otherwise rich iconology of alchemical text illustrations. However, in the works of the Flemish and Dutch genre painters this motif became closely associated with alchemy. Indeed, many of the artists cited above also produced paintings of alchemists. The association of the uroscopy icon with alchemy was fostered for several reasons. First, alchemists or chymists had long used glass flasks that were similar in shape to the classical matula. Second, Paracelsian iatrochemistry had given a boost to uroscopy through the distillation and quasi-chemical analysis of urine. Third, both classical alchemists and Paracelsian iatrochemists, like uroscopists, were the subject of numerous satires and biting pamphlets accusing them of imposture and fraud.

A selection of paintings from David Teniers the Younger illustrates how uroscopy and alchemy became visually melded. In many of his alchemist paintings Teniers employed one of the two classical satirical motifs in the foreground: the reading alchemist (Figure 5a) or the puffer alchemist (Figure $5 c)$. To show that the first motif is not a symbol of esteemed scholarship, it is useful to compare it with the Italian painting Jesus and the doctors of the Faith (Figure $5 \mathrm{~b}$ ) which Teniers took as the model for his reading alchemist. ${ }^{10}$ During the Renaissance the image of the twelve-year old Jesus among the doctors (from Luke, 2, 41ff.) was commonly used to demonstrate the inferiority of human scholarship compared to divine inspiration. In this painting (Figure $5 b)$ the artist accentuated the expression of the inferiority of human endeavors by giving the figure in the foreground a particularly stubborn and bookwormish demeanor, which Teniers meticulously copied in his reading alchemist (Figure 5a). Teniers' puffer alchemist (Figure 5c) is a variation of an older motif, the Antichrist/Satan who teaches gold-making to the people, illustrations of which became popular in $15^{\text {th }}$-century Germany (Figure $5 \mathrm{~g}$ ). Both Hans Weiditz (Figure 5f) and Albrecht Dürer (Figure 5e) employed that motif in their woodcut illustrations of the written satires of alchemy by Petrarch and Sebastian Brandt, respectively, who had made alchemy the epitome of forgery, fraud, greed, and moral corruption (Schummer 2006). Pieter Brueghel the Elder further developed this motif into a pictorial drama with an obsessed alchemist ruining his family (Figure $5 \mathrm{~d}$ ).

Teniers and his colleagues employed these two classical alchemy motifs but combined them with the classical uroscopy/imposture motif. Note that Figures $5 \mathrm{a}$ and $5 \mathrm{c}$ each show an alchemist in the foreground and a group of men in the background with one holding a flask in his hand like a uroscopist. In the next 'alchemist' image (Figures $5 \mathrm{~h}$ ), the composition of Figure $5 \mathrm{c}$ is almost inverted: the 'puffer' has moved to the background, while the reading alchemist now holds a flask in his hand. The pose of the alchemist in Figure $5 \mathrm{~h}$ is virtually identical to the classical pose of the urine inspecting quack 
doctor in Figure 5i. Thus, quack doctors and alchemists became exchangeable and merged towards one and the same motif in the works of Teniers and his colleagues.

\subsection{Satire continues}

Flemish and Dutch genre paintings of quack doctors/alchemists were extremely popular throughout Europe well into the $19^{\text {th }}$ century. Many of them were reproduced in etchings and widely disseminated during the $18^{\text {th }}$ and early $19^{\text {th }}$ centuries. In addition, painters from other countries employed or copied the motifs, such as Trophîme Bigot (1579-1650) in France, Pietro Longhi (1702-1785) in Italy, Franz Christoph Janneck (1707-1761) in Austria, James Northcote (1746-1831) in England, Carl Spitzweg (1802-1885) in Germany, William Fettes Douglas (1822-1891) in Scotland, and Newell Convers Wyeth (1882-1945) in the USA, but only few artists made original modifications (e.g. Figures $6 \mathrm{a} / \mathrm{b})$.

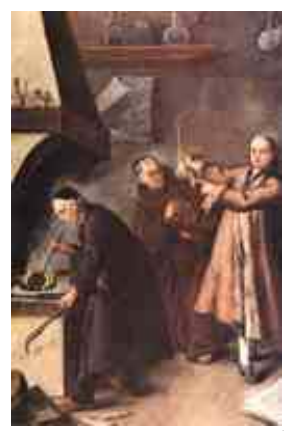

Figure 6a. Pietro Longhi (1702-1785): The Alchemists, c. 1757 , oil on canvas, $61 \times 50 \mathrm{~cm}$ (Galery Ca' Rezzonico Venice).

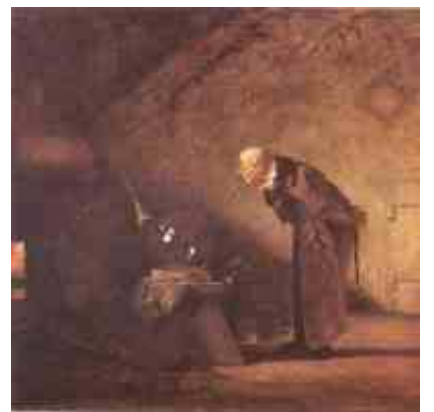

Figure 6b. Carl Spitzweg (1802-1885): Der Alchimist, c. 1860 , oil on canvas, $36 \times 38 \mathrm{~cm}$ (Staatsgalerie Stuttgart).

Once established as a symbol of quackery and fraud this motif was used for all kinds of satire. For example, Figure 7a shows a political satire by Temple West (c. 1739-1783) mocking King George III's misjudgment of Napoleon by depicting 'the little emperor' as a small figure in a large glass retort. Throughout the $19^{\text {th }}$ century, images based on this motif frequently included such nationalistic overtones, but the primary satirical attacks continued to be aimed at medicine (Figures $7 \mathrm{~b} / \mathrm{c}$ ). 


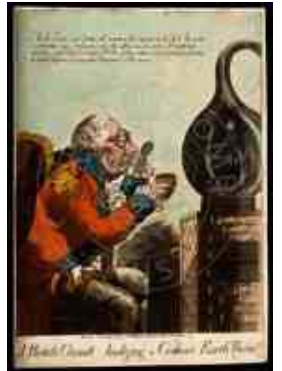

Figure 7a. "A British Chymist analizing a Corsican earth worm!!” Coloured aquatint by Temple West (c 17391783), published: London 1803 (Wellcome Library).

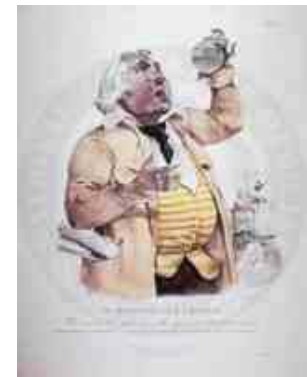

Figure $7 \mathrm{~b}$. "Le médecin aux urines: Oh! mon bon Dieu, quelle fièvre..." Lithograph after Charles Émile Wattier (1800-1868) (National Library of Medicine).

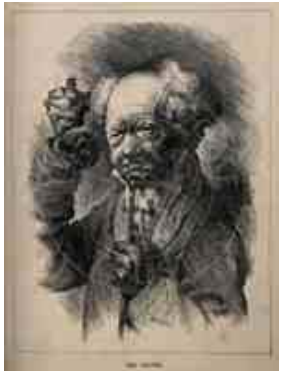

Figure 7c. "Nineteenth Century Doctor - still water gazing", Wood engraving after Adam Adolf Oberländer (1845-1923), c. 1890 (National Library of Medicine).

\subsection{Portraits of $19^{\text {th }}$-century chemists and their $20^{\text {th }}$-century transformation}

In general the image of a man holding up and gazing at a flask - the archetypical pose of $20^{\text {th }}$-century chemists - was carefully avoided by $19^{\text {th }}$-century chemists. Nobody wanted to be portrayed as an imposter or swindler. Based on our analysis of hundreds of painted and photographed portraits in various collections, $19^{\text {th }}$-century chemists preferred four types of portraits: ${ }^{11}$

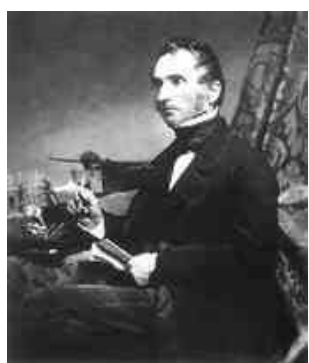

Figure 8a. Justus von Liebig (1803-73) (Edgar Fahs Smith Collection).

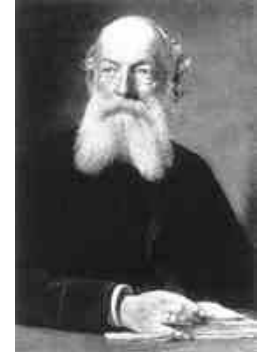

Figure 8b. August Kekulé (1829-96) (original painting from 1892) (Edgar Fahs Smith Collection).

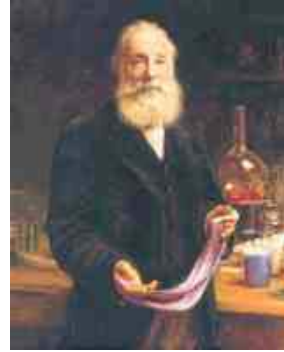

Figure 8c. William Henry Perkin (18381907) with a skein dyed mauve (original painting from 1892) (Edgar Fahs Smith Collection).

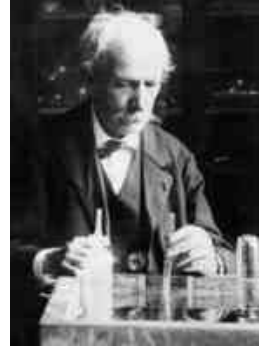

Figure 8d. Marcelin Berthelot (1827-1907)

(Edgar Fahs Smith Collection).

(1) Most chemists, particularly in the German and English traditions, are depicted sitting on a chair with some glassware or chemical apparatus in the background and books or notes in the foreground (Figure 8a). (2) In some portraits the only accessories are books, indicating the scientist's strong 
theoretical orientation (Figure 8b). (3) A third group of particularly English chemists are presented with their inventions, which suggests their ambition for technological applications of chemistry (Figure 8c). (4) Finally, a fourth group, consisting particularly of French chemists, are depicted working in the laboratory, and it is only here that some slight association with the quack/imposture motif sometimes appears (Figure $8 \mathrm{~d}$ ).

How then did this pose become so popular among $20^{\text {th }}$-century chemists? We suspect that commercial artists and photographers, whether consciously or not, gradually manoeuvred chemists into that pose and that chemists were increasingly uninformed about its negative symbolism. Eventually, without a clear understanding of its cultural and historical implications, they unwittingly embraced as the icon of their professional identity a symbol of imposture and fraud that had been firmly established for centuries.

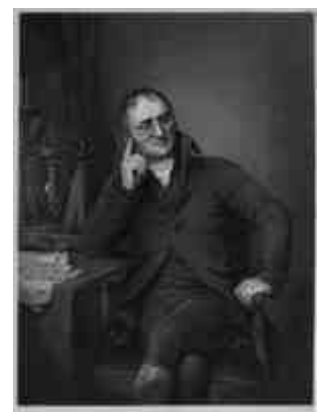

Figure 9a. Portrait of Dalton; engraving by William Henry Worthington (c.1795-c.1839) after a 1814 painting by Joseph Allen (17701839) (Edgar Fahs Smith Collection).

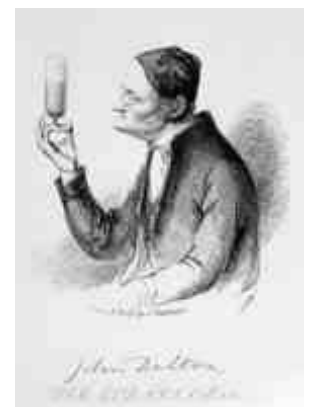

Figure 9b. Caricature of Dalton, drawn and etched by James Stephenson (1808-1886), probably from 1882 (Edgar Fahs Smith Collection).

To support our thesis we analyze three series of portraits of eminent $19^{\text {th }}$ century chemists in which the classical uroscopy/imposture motif gradually moves from satirical caricature to serious portraiture. Figure 9a shows John Dalton (1766-1844) in typical portrait type 1, i.e. with some chemical apparatus in the background and books or notes (here, his atomic formulae) in the foreground. This painting by Joseph Allen (1770-1839) was definitely made during Dalton's life and certainly with his agreement. In contrast, Figure 9b shows a later caricature (probably from 1882) by James Stephenson (18081886) of Dalton as President of the Literary and Philosophical Society of Manchester, which illustrates that the uroscopy/imposter motif was deliberately applied to chemists in $19^{\text {th }}$-century satire. Although the vessel he gazes at is somewhat unusual, it is clearly a version of the uroscopy/imposter motif. Because Dalton was famously color blind - he published the first account on what in England is still called Daltonism (Dalton 1798) - and because classi- 
cal urine inspection was focused on color, we may assume an additional irony in the caricature. Moreover, Dalton gazes at the vessel as if he was reading a book, which one would expect from the president of a literary society. Thus, the caricaturist employed the uroscopy/imposter motif and adjusted it with subtlety to the case of Dalton: The president of the literary society cannot read books and instead prefers reading liquids (urine), but he is even unable to do that because of his color blindness. While the satirical content of this image was certainly clear for contemporaries of Stephenson, later viewers might have misunderstood it as a caricature of a scientists engaging in overly pedantic empirical work in chemistry; if only he would lower the vessel a bit and look more relaxed, he might be viewed as the perfect experimental chemist.

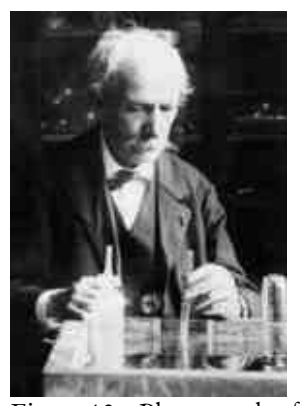

Figure 10a. Photograph of Berthelot, probably late 19th century (Edgar Fahs Smith Collection).

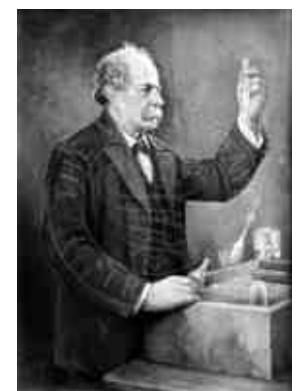

Figure 10b. Oil painting of Berthelot by Harry Herman Salomon (1860-1936) after a photograph, early 20th century (Wellcome Library).

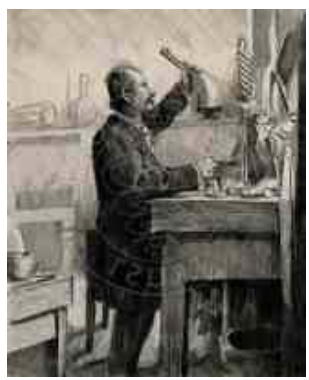

Figure 10c. Caricature (mirror image) of Berthelot by unknown artist, probably early 20th century, pencil on paper (Wellcome Library).

Our second example is a series of portraits of Marcelin Berthelot (1827-1907) in which, unlike in the case of Dalton, the uroscopy/imposture pose already appears in what seems to be a serious painting, before it was actually transformed into a proper satirical caricature. Figure 10a is a well-known photograph of Berthelot at work in a laboratory from the late $19^{\text {th }}$ century. He is looking down at his work-bench where in his left hand he holds a test tube as if he is preparing to run a reaction. Figure $10 \mathrm{~b}$ is an oil painting of Berthelot by Harry Herman Salomon (1860-1936) based on a photograph taken in the late $19^{\text {th }}$ or early $20^{\text {th }}$ century and perhaps painted after Bertholet's death. If you compare both images (the setting, equipment, and dress), it is obvious that the painting was made either directly after the photograph in Figure 10a or from a photograph taken on the same occasion. Thus, Salomon either modified the pose of the photograph or chose another one from the set to present Berthelot in a pose that almost exactly matches the classical uroscopy motif, except that the flask is replaced with a test tube. Since the painting 
otherwise fits the classical genre of portraiture, we may assume that the reference to the uroscopy motif was meant only as a mild satirical allusion. One might suspect that at the turn of the century many viewers no longer understood the allusion and its symbolic meaning. However, even if the symbolic knowledge was beginning to fade, it was still present, as a further transformation of Berthelot's portrait illustrates. To leave no doubt of the connection to uroscopy, a later unknown caricaturist lifted Berthelot' arm a bit higher and replaced the test tube with a urinal, now the modern version that is still used in hospitals today (Figure 10c).

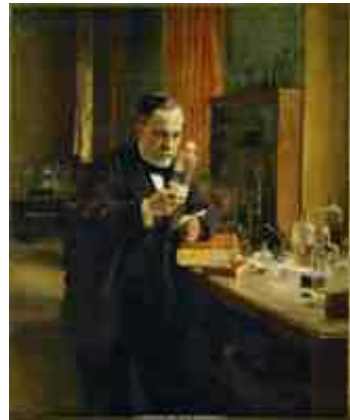

Figure 11a. Painting of Pasteur by Albert Edelfelt (1854-

$1905), 1885$, oil on canvas, 1,54 x $1,26 \mathrm{~m}$ (Musee d'Orsay, Paris ).

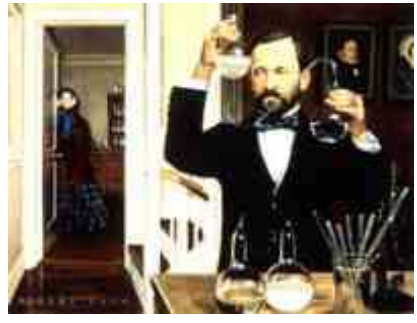

Figure 11b. Painting of Pasteur by Robert Thom (1915-1979) from the 1950s.

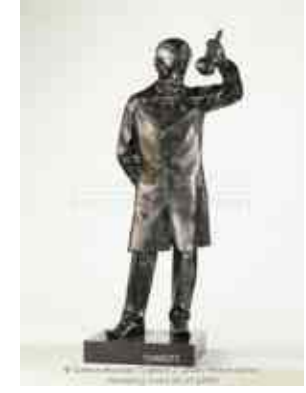

Figure 11c. Bronze statue of Pasteur, probably early 20th century (Science Museum)

The famous 1885 painting of Louis Pasteur (1822-1895) by Albert Edelfelt (1854-1905) is probably the first authorized portrait of a $19^{\text {th }}$-century chemist that appropriates the classical uroscopy/imposter motif without being a satire or bearing deliberate satirical allusions (Figure 11a). Given Pasteur's fame, particularly in the early $20^{\text {th }}$ century, and the significance of the painting, it is likely that this image considerably contributed to making this pose the icon of the chemical profession. Nevertheless? There are still differences between it and the classical motif which a superficial viewer of the portrait might ignore. Pasteur holds a bottle rather than a flask, the bottle is filled with a solid instead of a liquid, and he looks down at the bottle in his right hand and a paper note in his left hand as if he were comparing them. In Robert Thom's portrait of Pasteur from the mid-20 th century (Figure 11b), these differences are corrected: Pasteur gazes at the liquid-filled flask at eye level. In addition, since Thom painted this portrait as part of his extensive series of paintings of "historical moments in science and pharmacy” (Metzl \& Howell 2004), he was certainly aware of the historical iconology and symbolism of his image. The image was intended to capture Pasteur's experiments 
disproving the spontaneous generation of life. Anyone familiar with the history of these experiments would know that it is not the flasks but the connection between the flasks that was crucial to Pasteur's experiments. The connection is visible in Thom's painting, but the emphasis is clearly on the flask, so as to repeat with slight modification the classical uroscopy/imposter motif. A clear reiteration of the motif appears in the bronze statue of Pasteur in Figure $11 \mathrm{c}$, which is probably from the early $20^{\text {th }}$ century when many such statues were created to commemorate Pasteur's fame. It is unfortunate that, although today's chemists might consider this statue a tribute to Pasteur's greatness as a scientist, it is actually fraught with unsavory historical allusions.

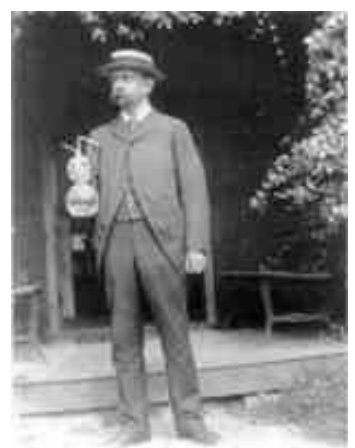

Figure 12. Photograph of Charles F. Chandler (1836-1925), late 19th/early 20th century (repr. from Bowden 1997, p. 154)

Misunderstandings of cultural symbolism can be particularly problematic if one deliberately strives to create a professional identity. A chemist with such an ambition was Charles F. Chandler (1836-1925). He was co-founder of the American Chemical Society, and its president in 1881 and 1889, and cofounder of the Journal of the American Chemical Society and its predecessor, the American Chemist (1870-7), which he co-edited with his brother. He was also ,an organizer and first president (1898-1900) of The Chemist's Club, a club whose goal was to foster a social and professional identity in the chemical community" (Bowden 1997, p. 155). It must have been during these years that the photograph shown in Figure 12 was taken: Chandler in front of his porch under a tree with suit, tie, and hat, holding a flat-bottom flask in his right hand. Although it is a variation of the classical uroscopy/imposter motif (e.g. Figure $4 b)$, its strong resemblance to the classical image suggests that he had seen such images before but was probably unaware of its negative historical legacy. By all indications this is an amateur photograph, so we can assume that artists or professional photographers did not influence his choice of 
pose. Rather like a self-portrait, it shows how Chandler himself - and thousands of chemists since then - chose to portray the visual identity of their profession.

The pose of a man holding up and gazing at a flask has changed in meaning over the past nine centuries. Originally it was a professional icon of the newly established academic medicine, which combined empirical diagnostics with causal knowledge. As the validity of the diagnostic tool was debunked, it came to represent 'merely empirical medicine' without deeper knowledge and ultimately became a symbol of quackery and imposture, first in medicine and alchemy and then as a general satirical motif for close to four centuries. When chemists, assisted by commercial artists, made this motif their professional icon at the turn to the $20^{\text {th }}$ century, its satirical associations were still alive. Since this pose now represents chemistry, and more generally experimental laboratory science, it might be easy to conclude that its debased associations have disappeared. However, we would argue that such a ready dismissal would be inappropriate. As with all powerful iconic imagery that possess a long, and predominately distasteful, historical lineage, the negative implications of that image can never be completely suppressed in the public consciousness. Even if present day viewers of such images are no longer overtly aware of their negative cultural connotations, the choice of early $20^{\text {th }}$ century chemists and artists to make this pose the visual icon of chemistry has indirectly influenced the public perception of the chemical profession. Ultimately, that choice confirmed and reinforced the negative attitudes of those who were already critical of chemistry before, and it is this historical legacy that lives on in the non-visual public images of chemistry today.

\section{Chemical Plants: The Panoramic View}

Like the stereotypical chemical portrait that emerged out of a long history of science portraiture, depictions of chemical plants developed from the broader history of industrial landscape paintings and drawings. In this section we analyze typical early $21^{\text {st }}$-century photographs of chemical plants against this art historical background. We argue that the stereotypical features of these photographs break with the important art historical traditions most often used to depict industry and instead rely on art historical traditions that were not typically used to depict industrial scenes. In doing so, we suggest that today's photographs of chemical plants employ a visual strategy that sanitizes the negative cultural associations of chemistry while simultaneously embracing a demeaning kitsch aesthetic. 


\subsection{Industrial landscape: historical traditions}

Since the $18^{\text {th }}$-century period of industrialization, artists' renderings of industry began to express a conflicted reaction to industry in the larger culture, a response that is at once celebratory and admiring and a site of distain and distrust. ${ }^{12}$ During the British romantic period these responses were expressed through renderings of the industry within the tradition of the picturesque or sublime landscape painting. A prototypically sublime rendition of industry is famously captured in Philippe Jacques de Loutherbourg's 1801 painting Coalbrookdale by Night (Figure 13a).

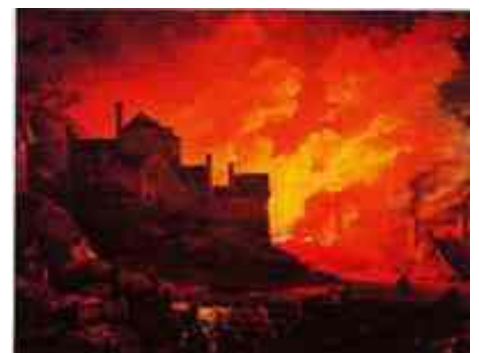

Figure 13. a) Philippe Jacques de Loutherbourg, Coalbrookdale at Night (1801) (repr. from Frese 2000, p. 3)

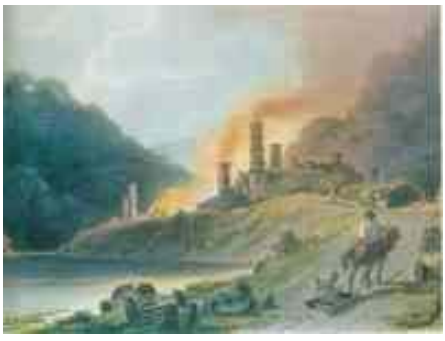

b) William Picket for Philippe Jacques de Loutherbourg Iron Works, Colebrook Dale (1805) (repr. from Klingender 1968, p. 111)

Coalbrookdale, the center of early English iron works and therefore an engine of English prosperity during this time period, was itself a conflicted site where the quintessential English countryside was, as expressed by the renowned agriculturist Arthur Young, ,too beautiful to be much in union with the variety of horrors spread at the bottom; the noises of forges, mill etc., with their vast machinery, the flames bursting from the furnaces with the burning of coal and the smoke of the lime kilns" (Briggs 1979, p.13). This painting and an aquatint of Coalbrookdale from 1805 by William Pickett for Loutherbourg's book on The Romantic and Picturesque Scenery of England and Wales (Figure 13b) ${ }^{13}$ together encapsulate the complexities of the attitude toward industry in England at that time. While Loutherbourg's painting stands as an emblem of the fear and mystery articulated by the Burkian sublime (see Section 3.3), the later aquatint transforms Coalbrookdale into a relatively benign picturesque landscape for English tourists. Later in the $19^{\text {th }}$ century artists in various traditions, including the impressionists, sometimes placed industrial sites harmoniously into natural landscapes or towns. ${ }^{14}$ In early $20^{\text {th }}$ century North America, images of the industrial landscape were usurped by powerful industrialists such as Herbert Dow (Frese 2000) and Henry Ford (Troyan \& Hirshler 1987, pp. 17-21), who commissioned artists to celebrate their economic prowess and enhance their public relations. Natu- 
rally these paintings provided a positive, and suitably unthreatening, image of the industries they depicted. For these, unlike earlier images of industry such as Coalbrookdale at Night, therefore, we can unambiguously read the smoke coming out of the chimneys as a symbol of economic productivity and wealth rather than as a noxious indicator of industrial pollution (Figure 14).

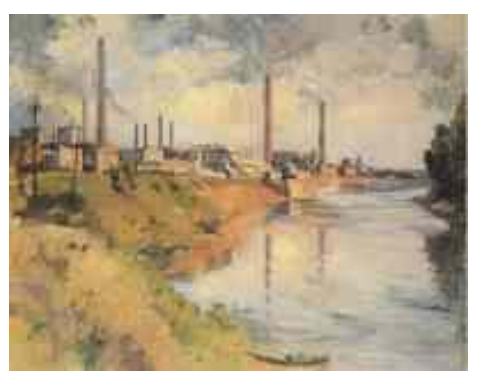

Figure 14. Arthur Henry Knighton-Hammond, Looking Down the Tittabawassee River at the Dow Chemical Plant (1920) (repr. from Frese 2000, p. vi), permission of The Hebert H. and Grace A. Dow Foundation.

A varied representation of industry can also be found in images of workers in industrial settings (Figure 15). In many paintings of this genre the workers are rendered as heroic and hard-working and it is the representation of their surroundings that expresses the artists' attitude toward industry itself. A typical early example is Joseph Wright's An Iron Forge (Figure 15a).

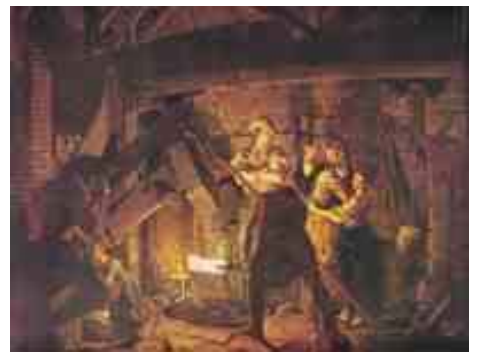

Figure 15 a) Joseph Wright of Derby, An Iron Forge (1772) (repr. from Daniels 1999, p. 52)

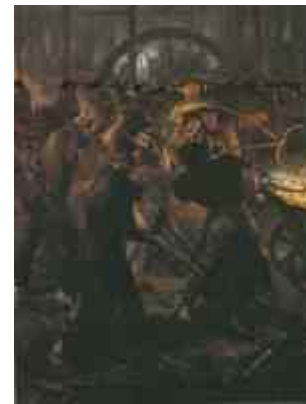

b) Adolf von Menzel, Iron Rolling Mill, detail (1875) (repr. from Fried 2002, p. iii)

Using his trademark chiaroscuro technique, this middle-class artist painted the iron workers in a picturesque setting being observed by affluent tourists and their curious children apparently seeking, in one critic's words, a „thoughtful balance $[\ldots]$ between sense and sensibility, between the prosaic, necessary task efficiently performed which is going to benefit mankind, and 
the fear or amazement that its accomplishment inspires" (Nicoldon 1968, p. 50). It also, however, reveals the darker side of the picturesque in which the working classes were aestheticized for the consumption of the affluent. In $19^{\text {th }}$-century realist paintings, such as Adolf von Menzel's Iron Rolling Mill, this idealized view of industrial work is superseded by interiors of industrial plants that are overcrowded with workers, replete with machinery, and overheated by steam and fire (Figure 15b). In the early $20^{\text {th }}$ century depictions of industrial workers became more overtly politicized emblems of the socialist (and national-socialist) movements in many countries. As seen in the soviet era propaganda poster Let's consolidate the victory of socialism in the USSR! (Figure 16) such images accorded the workers with even more blatant heroic status than those of the $18^{\text {th }}$ and $19^{\text {th }}$ centuries.

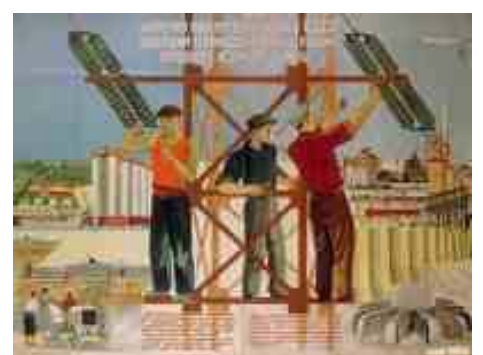

Figure 16 a) Konstantin Vyalov, Let's consolidate the victory of socialism in the USSR!, 1932, permission of the Internationaal Instituut voor Sociale Geschiedenis

\subsection{Chemical plants as architectural photographs}

In current photographs of chemical industry, ${ }^{15}$ the classical art historical motifs of industry, such as plants harmoniously embedded in natural landscapes, smoking chimneys as a symbol for prosperity, and heroic workers are virtually absent. Instead, the typical modern image, like those shown in Figure 17, is remarkably reiterative and self-reflexive. The most important pictorial elements of chemical plant photographs are smokestacks, towers, storage tanks, piping, and conduits, with towers or smokestacks typically growing (by perspectival correction) straight out of the bulk of the plant into the sky, taking up two thirds or more of the image (Figure 17a-c). Most of the images employ special lighting effects: industrial plants are imaged shortly before or after sunset to ensure vibrant skies that recall the colorful pictorial liquids filling glassware in most stereotypical representations of the laboratory equipment (see below), while some photos, taken at night, foreground buildings with spectacular interior illumination (Figures $17 \mathrm{~d}$-e). 

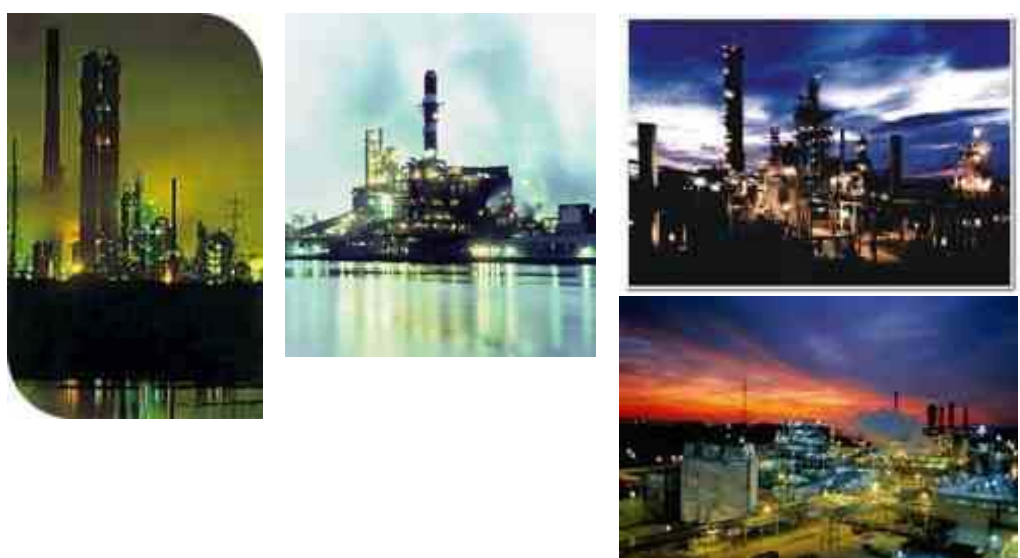

Figure 17: Stereotypical contemporary photographs of chemical plants (from the websites: a) http://www.liquiteck.com/fs/chemical.htm, b) www.investtnt.com/invest/chem.htm, c) http://www.cwc.gov, d) http://www.matcon-cone.com/chemical.htm, e) http://www.mottcorp.com/industry/process/applications.htm).

In addition, modern images of chemical plants are typically static rather than dynamic. They are most often portrayed without smoke coming out of their smokestacks and without people working near or with the equipment. These images, in addition to the curious fact that the plants appear to be neither in operation nor in ruin or decay (in fact, are in pristine condition), disconnects them from the picturesque industrial landscapes of the $18^{\text {th }}$ and $19^{\text {th }}$ centuries. Furthermore, in the absence of people, modern photographers of chemical industry belie their debt to more overtly propagandistic images of industrial workers and industrial sites, e.g. in Soviet social realism and American WPA murals, and to their historical progenitors in the artistic tradition of genre paintings. Finally, the fact that the photographs are situated away from towns or cities and have no smoke emerging from their smokestacks divorces them from a variety of conflicting pictorial traditions: the meliorative nature of 'man's' interaction with nature, the contrasting blight of industrialization in the landscape, and the economic prowess of a particular nation. By choosing to photograph them as static structures free of humanity in a background featureless except for the atmospheric essence of the sky, photographers of chemical plants would seem, in fact, to forcefully sever their connection to earlier artistic traditions. Indeed, the very contextlessness of the chemical plants shifts them from early $20^{\text {th }}$ century industrial images that reflected nationalist pride to the post-nationalist identity of the globalized corporation.

To what do these images owe their historical debts if not the industrial landscapes of art history? Because of their focus on smokestacks, tanks, and 
other equipment essential to industrial-scale chemistry, and because of their lack of context, one might be tempted to interpret them as representationally realistic and therefore to fit, perhaps, within the tradition exemplified by Bernd and Hilla Becher's bleak industrial landscape photographs taken from 1959 forward (Becher \& Becher 2002). It might also be easy to dismiss these repetitive photographs as simply the products of commercial photographers commissioned by chemical industry, and thus being of little visual interest. Some would say that they simply become boring; yet others would point out that these are precisely the qualities that make them interesting: their stance of disinterestedness, their visual isolation, their juxtaposition of an industrial, unnatural subject against an atmospheric sky, and the very fact that they are reiterative. Indeed, in this latter reading, if instead of being produced in a commercial context, the photographs had been created as 'high' art, a critic might comment that they fit within the construct of ironic banality explored by many of today's most influential visual artists.

Furthermore, when we focus less on the subject materials of the photographs and more on their composition, especially the use of perspective and atmospheric effects, we find that the formal aspects of these images borrow from various traditions. First, the isolation of the plants, which contrasts so markedly with most early representations of industry, impresses upon the viewer their lack of context. Framed by the edge of the photographs, chemical plants are portrayed without reference to the land or people that their presence might affect, either positively or negatively. This cropped frame removes them from all external reference points allowing the photograph to symbolically eliminate the chemical plants potential for contamination. The static, unpeopled content of the photographs, in collusion with the reiterative character of the images, thus simultaneously produces and reinforces a sense of containment and safety. Important to this effect is the photographic perspective, which aligns the plants with early architectural photographs of castles and cathedrals that contain similar formal features such as towers and conical elements (Figure 18) (Robinson \& Herschman 1987, pp. 2-55). Like those images, these are often frontal shots from ground level viewpoints, which emphasize the vastness of the structure. Although less frequently, some chemical landscape photographs are shot from an elevated position, a perspective also common in early architectural photographs of cathedrals and castles. Ironically, like the genre of landscape painting itself, which marked an artistic shift from Classic to Romantic and Christian to secular (Mitchell 2002, p. 13), images of chemical plants transpose the art historical perspective used primarily to image cathedrals (Christian) and castles (classical) into the ultimate site of secularization - industry. By a unique legerdemain, however, the simple fact that these photographs participate in this tradition has the simultaneous effect of hallowing the industrial site and placing it under the 
symbolic aegis that cathedrals and castles historically sustained. In effect, these photographs invite a symbolic exchange in which the industrial site can stand in for the signs of governance and social order historically signified by castle and church.

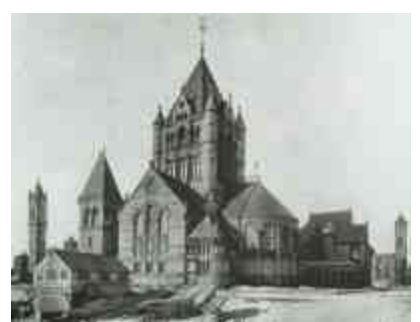

Figure 18. Examples of early architectural photographs of castle and cathedral, a) Anonymous, Boston Trinity Church (1876) (repr. from Robinson 1987, p. 5)

\subsection{Chemical plants as sublime landscape}

Even with these traditions in mind, however, photographs of the chemical landscape may not initially impress the viewer with an experiential sensibility beyond that associated with the magnitude of the plant. From an art historically informed perspective, however, it is clear that the composition of such photographs introduces an emotive element which links their lineage to the sublime landscape images of the $18^{\text {th }}$ and $19^{\text {th }}$ centuries. Borrowing from the atmospheric effects of J.M.W. Turner and the grandiosity of Casper David Friedrich (Figure 19), they are expansive in scope, employ the sky as „the key note, the standard of scale, and the chief organ of sentiment" (Constable 1998, pp. 50f.), and operate on a vertical rather than horizontal axis. In addition to displaying the proportional conventions of sublime landscape painting, the use of special lighting effects in chemical landscapes has a clear allegiance to the atmospheric effects found in Romantic era industrial landscape paintings. As epitomized by Loutherbourg's Coalbrookdale by Night (Figure 13a), this subgenre of paintings represents some of the most dramatic atmospheric effects from the sublime landscape tradition.

Previous studies of landscape have shown that artists' representations of 'natural' landscapes are not naïve, realistic representations of nature, but are undergirded with cultural narratives (e.g. Mitchell 2002). Thus, for many art historians and literary critics even the most 'natural' landscape paintings and photographs express social hierarchies, labor relations, and imperialism in such a way that they effectively contain class conflict, labor unrest, and concerns about national identity - in the same way that modern chemical land- 
scape photography contains fears concerning labor practices, industrial safety, and environmental contamination. Within the paradigm of landscape painting, nature itself is a human construct laden with conventions that make it comprehensible as 'landscape', and artistic representations of the landscape overtly articulate these conventions. Similar conventions are smuggled into the decidedly unnatural vistas of the chemical landscape.

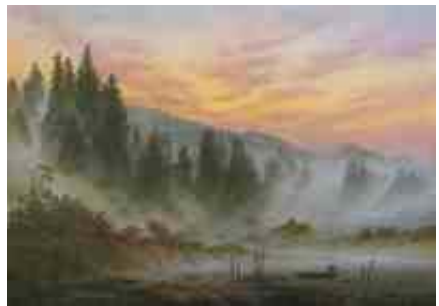

Figure 19. a) C.D. Friedrich, Morning (1821) (repr. from Koerner 1990, p. 202)

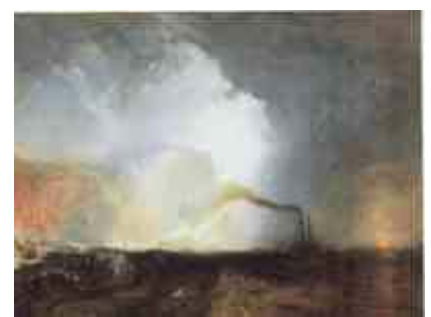

b) J.M.W. Turner, Staffa, Fingal's Cave (1832) (repr. from Rodner 1997, plate 4)

By acknowledging the constructed nature of landscape and the articulation of its visual conventions in landscape painting, we can understand visual representations of the industrial landscape as an extension of traditional landscape painting. The landscape conventions of the picturesque and sublime, which are readily visible in $19^{\text {th }}$ century paintings of industry (Figure 13), are cloaked in the images of chemical plants with which we are concerned. When we consider contemporary images of chemical industry within the larger landscape tradition, rather than simply as photographs of chemical plants, we secure the connection of these images to sublime landscape painting. As noted by Snyder (2002), $19^{\text {th }}$-century commercial landscape photographers „did not escape landscape conventions; they adopted and reformulated them". Thus, like Carleton Watkins who took industrial photographs for the California State Geological Society in the $19^{\text {th }}$ century, early $21^{\text {st }}$ century photographers of chemical plants have adopted and reformulated a formal and philosophical link to the sublime tradition. Formally, their photographs are composed along the same physical scale, with the same vertical forms, and with the same attention to atmospheric effects; philosophically, they are framed by Edmund Burke's and Immanuel Kant's aesthetic theories of the sublime.

In his Pbilosophical Enquiry into the Origins of Our Ideas of the Sublime and Beautiful (1757, pt. II), Burke distinguished beauty as a form of pleasure, from the sensation of the sublime, which is caused by imagined threats to our existence that, if compared to real threats, are accompanied by delightful relief. For instance, an image of the devastating power and grandeur of nature can cause us to experience the emotion of the sublime if we are simultane- 
ously aware that the threat is only imagined. In the chemical landscape this view of nature is transmogrified into an industrial site and the trigger for the sublime experience is reconstituted as a fear of chemicals and the power of the chemical industry. ${ }^{16}$ In Kant's Critique of Judgment (1790, $\mathbb{S}$ 23-9), the delight of the sublime results from a self-reflection of the human mind, which further helps us to understand today's photographs of chemical plants. From this perspective when nature through her grandeur and power intimidates our sense of self as physical beings and makes us look and feel small and powerless, we can resort to the capacities of human reason that is ultimately powerful. Thus, according to Kant, the original fear and intimidation produced by nature is turned into the delight of the sublime once we recognize our capacity to comprehend and ultimately control its seemingly overwhelming might. By a clever displacement, when industry, such as the Coalbrookdale industrial site, is placed into natural landscape or replaces nature all together, as in today's chemical landscapes, the Kantian sublime assumes a new dimension: industry becomes the object by means of which the human mind can recognize its own greatness.

\subsection{Chemical plants as kitsch}

Kitsch has been a topic of debate among art/cultural critics and scholars for more than a century (Kulka 1996, pp. 13-22). The most influential critics on the subject include Clement Greenberg (1909-1994) and Hermann Broch (1886-1951). Greenberg (1939) defined kitsch as „popular, commercial art and literature” (as opposed to avant-garde art and literature) that „is a product of the industrial revolution which urbanized the masses of Western Europe and America” and ,is mechanical and operates by formulas [... and] vicarious experience and faked sensations". Similarly, Broch (1969) considered kitsch a "system of imitation" that corrupts real art (in his case the art of Romanticism) serving as an "element of evil in the value system of art" (Broch 1969). More recently scholars have attempted to recuperate kitsch from these harsh critiques by reframing it as a distinct aesthetic without regard to class-based tastes. These include Robert C. Solomon's (1991) defense of sentimentality in art, Sam Binkley's (2000) argument "for a uniquely kitsch aesthetic that employs the thematics of repetition, imitation and emulation as a distinct aesthetic style" and Kulka (1996, pp. 1-12) who conservatively attempts to reduce kitsch to an aesthetic category (like the grotesque or the beautiful) that is objectively deficient as an art form rather than subjectively a matter of taste. In sum, despite the complexities and inconsistencies between the arguments articulated by these critics and others, kitsch can be understood as a sociocultural phenomenon (normally connected to the 
development of the middle-class in the $19^{\text {th }}$ century) and a debased artistic sensibility with roots in the Romantic era.

Broch made clear how the aesthetic ideals of Romanticism became the progenitor of what we now know of as kitsch: although not kitsch, Romantic art is "the mother of kitsch and that there are moments when the child becomes so like its mother that one cannot distinguish between them" (Broch 1969, p. 62). From this perspective Romantic era paintings like Friedrich's Wanderer Above the Sea of Fog (1818), Schinkel's Medieval City on a River (1815) and even Loutherbourg's Coalbrookdale by Night (Figure 13a) cross into the realm of kitsch because they contain ,a range of references to high or legitimate culture" (Ross 1989, p. 145), but in doing so rely on the use of formal clichés and an overwrought sentimentality that undermines their artistic intentions. This slippage between Romanticism, and in particular the Romantic sublime, and kitsch is also found in modern chemical landscapes. The expressive note of these images manifests itself in the expanse of richly atmospheric sky juxtaposed against the chemical plant. That the sky is the intended site of emotionality in these images is made clear when viewed in contrast to the typical images of academic chemistry buildings, which do not include such skies and thus strike one as mundane and visually uninteresting. The sky in photographs of chemical plants, on the other hand, adds an element of over-sentimentality to the image that potentially links it to a disingenuously emotive stance and threatens to topple the images from sublimity into kitsch. Viewed in this way, these ornate skies imitate those found in sublime landscape paintings and the images themselves are therefore merely draped in the most overt trapping of this tradition. Through this lens, these images like the classic visual clichés of kitsch (e.g., exaggeratedly round eyed children and puppy dogs (Solomon 1991) provide a falsely benign image of the world - where chemical plants are only associated with the production of goods that yield 'better living through chemistry' and never with the realities of chemical pollution and toxicity.

Kitsch developed as a consequence of the mechanization of massproduction along with the simultaneous growth of the middle-class in the $19^{\text {th }}$ century (Kulka 1996, pp. 13-22). The ability to cheaply reproduce art (as posters, postcards, etc.) gave the middle-class access to a simulacrum of images that were previously available only to the privileged. Cheap reproduction yielded a new aesthetic based on the imitative rather than the authentic. (In an ironic twist to this history, kitsch has since been hijacked by the elites of the world of art). Chemical landscapes are therefore doubly endowed with the mechanized qualities of kitsch. They imitate the art of the sublime tradition and they have a reiterative impulse - so that each image mirrors the content and structure of the others - yielding a mass-produced quality. Through sheer repetition images of chemical plants become commonplace inuring the 
viewer to their potential hazards and ultimately rendering them as culturally neutral, even inert, objects. Thus, although kitsch might be viewed as the poor, uneducated cousin of the sublime, it, like the sublime, has the power to subdue the dangerous power of chemical plants for the viewer of such images.

Whether viewed through a sociocultural, art historical, or aesthetic lens, chemical plant landscapes at once revere and deflate the actualities of chemical industry. When viewed in the context of architectural photography chemical plants literally and metaphorically stand in for the castles and cathedrals of earlier photographs, replacing these iconic symbols of power (monarchy and church) with a later day equivalent - industry. Like architectural images of castles and cathedrals, and unlike early depictions of industry, current images of chemical industry decontextualize and sanitize their presence in the larger landscape, visually minimizing their potential for hazards. This dichotomy is recast by a reading of these images within the framework of the sublime and kitsch. In this aesthetic context, chemical plants become symbolic of the sublime power of the human mind to both create and control chemical industry and its products, while kitsch, when viewed as an overwrought visual extension of the romantic sublime, diminishes their cultural power through cliché and reiteration.

\section{Abstraction}

\subsection{Chemical plants: close-up view}

An alternative but also common image of the chemical plant provides a closeup perspective of the tubes and towers discussed as primary elements in the previous section. Even more than those of the panoramic chemical plant, however, these cropped images decontexualize the plants from their sociocultural implications - formally obscuring their relationship to any past or present landscape, industrial or otherwise. As shown in Figure 20 they are sometimes photographed from above, but, more commonly from below, a 'worms-eye' perspective that can make the viewer of the photograph feel slightly off-kilter and reverentially endows the plants with a beauty not found in the chemical plant landscapes we have just discussed. ${ }^{17}$

With these changes in perspective also comes an alteration in the art historical associations of the images, albeit one with a more positive valence. Thus, instead of being aligned with the fakery of uroscopy or the kitschyness of the overwrought sublime landscape, these images participate in the 'high- 
art' aesthetics of early $20^{\text {th }}$-century modernism. In particular, the myriad of ordered yet entangled tubes in these images recall the art of the Machine Age, which exalted the rise of industrial culture as a symbol of rationality and hope after World War I. A proto-Machine Art had emerged in the years just prior to World War I when the epic-cubists, futurists, and constructivists (Herbert 1997) embraced the machine as a subject material for serious abstract art. ${ }^{18}$ By the 1920s a 'machine aesthetic' had developed that employed the geometric forms of abstract art but was essentially representational. Early in this time period the shift towards the representational is perhaps best exemplified by Fernand Leger, whose paintings often situated cartoonishly rendered people within backgrounds composed of mechanized and industrial elements (Figure 21a). By the 1930's many Weimar artists had assumed a philosophy of Neue Sachlichkeit that was reflected in a style of detached realism compared to the high emotionality of classic German expressionism (Guenther 1995, pp. 35-36). Most notable among these for our purposes is Carl Grossberg who painted colorful, often whimsical images of industrial sites including Kessel in Einer Raffinerie and Der Gelbe Kessel (Figure 21b). ${ }^{19}$ Ultimately the machine as the subject of art was realized in the aesthetic of 'machine purity' by the precisionist artist Charles Sheeler and others (Figure 21c). These American artists revered the inherent beauty of machines rendering them in a pristine fashion akin to those found in mechanical drawings. Although historians of machine-age art often tend to focus on an artist's fascination with the mechanical aspects of the machines they portrayed, as shown in Figure 21 the relationship of such art to chemical processes is just as, if not more, important. These artists not only employed tubular shapes as principle geometric forms in many of their compositions, which implicitly links their work, and much of the abstract art of that time, to the conduits and smokestacks associated with industrial chemistry, they often explicitly represented chemistry. This is clearly shown in Leger's Le Mécanicien which portrays a man holding a cigarette backgrounded by a small industrial plant with a smokestack which presumable indicates his status as a 'mechanic' (Figure 21a); Grossberg's Der Gelbe Kessel where a chemical tank is the primary subject of the painting (Figure 21b); and Sheeler's Ballet Mechanique which depicts a network of conduits carrying „,compressed air and excess gases between the power house and the blast furnaces” (Troyen 1987, p. 124) of Ford's River Rouge Plant. As demonstrated by these images there is a direct visual connection between the work of the machine-age artists and the abstracted images of chemical plants created by today's commercial photographers (see Figure 20).

The precisionists also rendered machines as pristinely devoid of grime and human interaction. As machine purists they, unlike the Dadaists of this same time period (who employed a machine aesthetic as social critique), embraced an aesthetic of the machine endowed with an optimism representative of the 
rise and promise of American industry, including chemical industry (Lugon 2003). In fact, for American precisionists in particular, the line between their art and the utopian promise of American industry was porous, enabling them to work as both fine artists and commercial artists without hesitancy and to employ the same visual tropes in both artistic spheres. ${ }^{20}$ These visual tropes were eventually subsumed by many commercial photographers and, as illustrated in Figure 20, are still employed today.
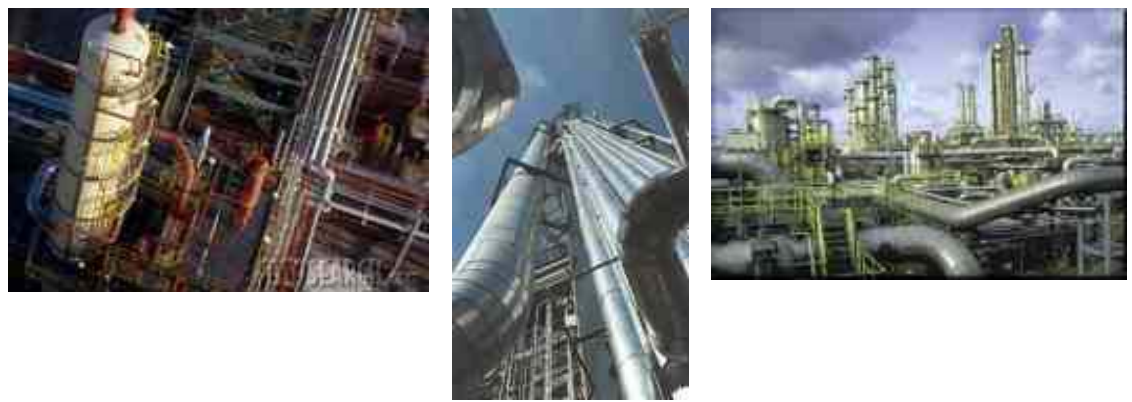

Figure 20. Typical close-up images of chemical plants: a) http://www.umsys-asia.com, b) http://www.uyseg.org/industryanimated/photoindex/chemical_plant.htm, www.flosteer.com/chemical.jpg.

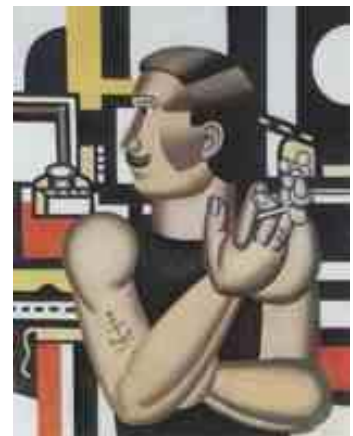

Figure 21. a) Fernand Leger, Le Mecanicien (1920) (repr. from Lanchner 1998, p. 193), (C) 2007 Artists Rights Society (ARS), New York / ADAGP, Paris

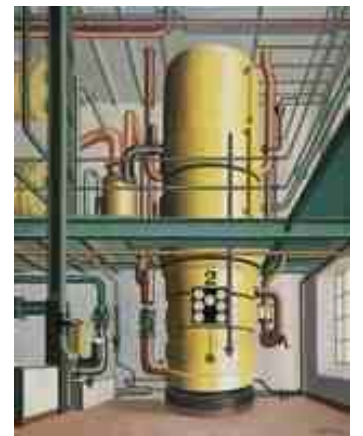

b) Carl Grossberg, Der Gelbe Kessel (1933) (repr. from Michalski 2003, p. 168), permission of Galerie Michael Hasenclever, München

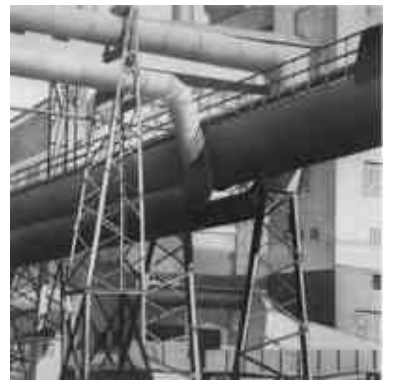

(c) Charles Sheeler, Ballet Mechanique (1931) (Troyen 1987, p. 125), permission of Memorial Art Gallery, University of Rochester.

Like the work of the machine purists, close-up images of chemical plants appear representational but in fact rely heavily on the formal canon of abstract art, including an emphasis on primary geometric forms juxtaposed into complex arrays akin to the work of the cubists. In theory, the geometric nature of these images reflects the order and rationality of the machines they 
depict, but, as Rutsky (1999, pp. 73-101) has argued, their relationship to abstract modernism ultimately separates their technological function from their form shifting them into a purely aesthetic realm. In their close-cropped askew perspective these images, like Machine Age photographs themselves, also reveal their connection to the abstract movement of avant-garde photography made popular by the Bauhaus photographer Lazlo Moholy-Nagy and others in the 1920s and 1930s who "strove to separate objects from their natural settings" by employing "disorienting viewpoints, radical cropping, strong figure-ground relationships, [and] compositions oriented on the diagonal" (Light 1995, p. 97).

\subsection{Glassware: the chemical still life}

Like the close-up images of chemical plants, many contemporary images of chemical apparatus play on the abstract tradition. Initially they appear simply representational, but closer inspection shows that they are not. As in Figure 22 the prototypical contemporary chemical 'still life' photograph is composed of a collection of various flasks and test-tubes containing colored liquids sitting on an indeterminate surface (i.e. not clearly a table or lab bench) or, more often, shot from an odd angle and/or so closely cropped that there is no recognizable surface. Their focus on decontextualized glassware provides little clue to how the equipment is manipulated by people in a laboratory environment. Instead, these images are intended to represent the discipline of chemistry. In fact, as we have shown in a previous paper, in popular visual culture images of prototypical chemical glassware such as flasks and test-tubes are emblematic icons of chemistry, and indeed of all of science (Schummer \& Spector 2007).

Unlike chemical plant abstractions, however, the formal aspects of many of these images have a strong allegiance to a particularly spare mode of still life painting rather than to Machine Age precisionism. This style, as exemplified by Giorgio Morandi in the mid $20^{\text {th }}$ century and later by William Bailey, express the neoclassical ideal of beauty through their simplicity, balance, and harmony (Figure 23a/b). Both of these painters worked within the still life tradition through their choice of subject material (bottles, plates, cups, and so forth sitting on tables) but at the same time altered the tradition by stripping it down to its bare essentials, leaving behind the elaborately crowded still lifes of earlier periods that admit decay and death as a marker of time in the form of animal carcasses, dying flowers, and insect infested fruit. ${ }^{21}$

Tony Cragg makes explicit this connection between images of chemical apparatuses and still lifes in his series Laboratory Still Life No. 1-4 (Figure 23c). Like Morandi and Bailey he strips the still life down to its bare essentials (in his case objects without even a table), but unlike these artists he em- 
ploys chemical flasks as his subject material imparting a sense of irony into his still lifes. Like these artists' still lifes, chemical 'still lifes' are generally simple and well balanced compositions (see Figure 22). Unlike Cragg's paintings, however, chemical 'still lifes' extract self-conscious irony through their institutional intentions. Instead, like the chemicals and chemical industry that substitute for nature in their manifestation of the sublime, an unintended irony emerges from the tension between beauty and danger in the chemical 'still lifes'. Renaissance still lifes sometimes seductively depict idealized fruits and vegetables, which on closer inspection actually show signs of decomposition and insect infestation. Similarly chemical 'still lifes' work on two levels those of the beautiful and the grotesque. Unlike the explicit (and whimsical) grotesque aesthetic of Renaissance still lifes, however, the association of chemical 'still lifes' with the grotesque is expressed only implicitly through the negative associations that chemicals often elicit from the public. ${ }^{18}$
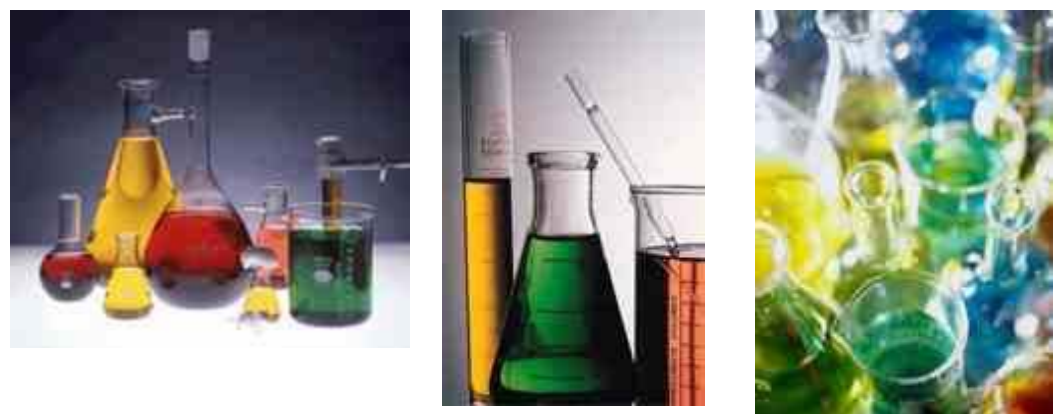

Figure 22. Prototypical Chemical Still lifes: a) http://www.philexport.ph/tops/tops2002/3q/, b) http://www.education.bham.ac.uk/programmes/pgrad/pgce/secondary/science/chem.htm, c) http://www.energywipe.com/WhatOurCustomersSay.htm.

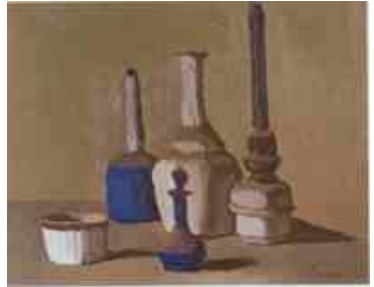

Figure 23. a) Giorgio Morandi, b) William Bailey, Strada Bianca Still Life (1941) (repr. from (1990) (repr. from Briganiti Abramowisz 2004, plate 10.6), 1991, p.120), (C) William Bailey, (C) 2007 Artists Rights Society Courtesy Betty Cuningham (ARS), New York / SIAE, Gallery, New York. Rome

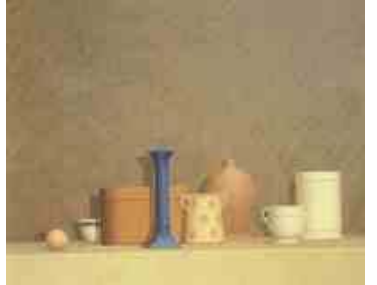

c) Tony Cragg, Laboratory Still Life No. 1, State 2 (1988) (repr. from Brown 1996, p. 67), courtesy the artist and Lisson Gallery, London. 
Tony Cragg was schooled as a chemical laboratory technician and we can assume that he was exposed to illustrations of chemical apparatuses in chemistry textbooks. It comes as no surprise, therefore, that his work reveals an intimate conceptual parallel to the long historical tradition of scientific textbook illustrations. Nevertheless, although Cragg's paintings are representational in so far as they depict actual chemical glassware, they are also unmistakably symbolic rather than didactic. Taken as scientific illustrations, his paintings would provide no guidance for performing an actual experiment. His images emblematize chemistry itself rather than depicting its processes.

Such depictions of chemical glassware, both in contemporary photographs and fine art, assume their emblematic and symbolic function through their historical lineage. From ancient Alexandrian manuscripts to medieval alchemical treatises, images of chemical apparatus were frequently interspersed with the text to illustrate the specific shape or construction required for an experiment (Obrist 2003). In Renaissance textbooks of distillation and metallurgy, such illustrations sometimes consumed larger parts of the volume, as in Biringuccio's Pirotechnia (1540). During the $18^{\text {th }}$ century such drawings gained in popularity, culminating in the inclusion of numerous detailed illustrations of distillation apparatus in one of the grand symbols of the Enlightenment, Diderot's Dictionary of Science, Arts, and Trades (Greenburg 2003, pp. 150-4) - ostensibly providing information to the educated reader on instrumental details. Starting with Lavoiser and continuing into the $19^{\text {th }}$ century, illustrations of apparatus became more accurate and gradually included some drawings that attempted to depict dynamic chemical processes, in alliance with the drive to legitimize and popularize chemistry (Golinski 1992). Illustrations in chemical textbooks and manuals sometimes showed apparatus with disembodied hands manipulating the glassware, which in theory could be used as guides for performing an actual experiment (Knight 2003). These drawings live on in chemistry laboratory textbooks today and effectively communicate how to set up or manually manipulate a particular piece of glassware (e.g., Williamson 2003).

Apart from their specific didactic purpose, however, images of chemical apparatus assumed a life of their own in the broader visual culture. Starting in the late $18^{\text {th }}$ century, they drew visual associations between chemistry, experiment, and Lavoisien empiricism (Stafford 1996, pp. 91-110), even though, as Beretta (2000) notes, the illustrations sometimes represented anachronistic chemical apparatus. They helped chemistry to assume the epistemological status of a respected science, to establish a professional identity, and to popularize itself to a broader public. In the late $19^{\text {th }}$ century the iconography for representing chemistry as a scientific discipline was fully developed, employing the same elements we find today. These included static and decontextualized drawings of flasks and test-tubes without any indication of how to use 
them (Knight 1996). Like the subjects of the Machine Age, the depicted apparatus became symbolically abstract and dissociated from its actual function.

Today's photographs of chemical glassware have largely replaced the woodcuts and etchings of earlier centuries, but still operate on two semantic levels. On the one hand, like Cragg's still lifes, they retain the representational content and associations of $19^{\text {th }}$-century chemistry. On the other, they symbolically represent contemporary chemistry. Thus, images of glassware filled with colored liquids are such potent indicators of chemistry that they are used as the icons of science, although the chemistry they represent is generally outmoded..$^{22}$ Moreover, once abstracted from their representational meaning, the images could become subject to graphical analysis and rearrangement both in photographic self-representations of chemistry and in fine art. Indeed, we contend that these images' conservative, backward-looking, symbolism has ironically led to their thoroughly modern rendition, allowing them to be loosed from any representational context and brought into the realm of pure aesthetics.

\section{Conclusion}

Like any other profession, chemists have been involved in shaping their public image through the production and dissemination of visual material that they believe best depicts their profession. Because these images are often created by commercial artists they are also consciously or, what appears more likely, unconsciously embedded within specific cultural traditions and conventions. Thus, unlike fine art representations of chemistry, ${ }^{23}$ chemists and commercial artists presumably do not seek originality (in a broad sense) but rather visual conventions that create immediate associations between the image and chemistry. It can be assumed that in these cases, chemists intend to show their science in a positive light but at the same time need commercial artists to produce images that 'excite' the eye. Therefore, within the highly delineated subject material and conventions that these images demand, they seek to create interesting and original images. Although perhaps less overtly articulated than their formalist qualities, these images also expose conceptual and psychosocial aspects of the chemistry they seek to represent. Visual images of chemistry are situated and perceived within the larger cultural context of chemistry - a science with a dual (some would say split) personality, at once academic and industry-serving, conceptual and applied - so that they express the multiple layers of the science itself. As a result they provide insights into how chemistry seeks to aesthetisize its representation in the larger 
culture while simultaneously exposing how the larger culture comes to understand chemistry through its visual representation.

A qualitative examination of the visual self-representation of chemistry reveals that three specific motifs prevail so strongly that they have assumed a stereotypical character: the image of a scientist holding up a piece of glassware and gazing at its contents as the key pose of chemical portraiture, chemical landscapes of smokestacks and conduits in atmospherically illuminated skies, and chemical still lifes of various flasks filled with colored liquids. In this paper we have examined these motifs within the broader culturalhistorical context. Not surprisingly, all three 'chemical' motifs can be traced back to longer traditions of the fine arts and popular visual culture, which have shaped both the visual conventions and the cultural meanings of today's chemical stereotypes. It turns out that, like the split identity of chemistry itself, these images represent a conflicted public identity for the discipline. All too often, as the chemical portraiture section of this paper demonstrates, commercial artists, who are likely not apprised of the artistic tradition in which they work, and the chemists who naïvely disseminate their selfrepresentations, unintentionally promulgate an image of chemistry based in a satirically debasing tradition. Or, as in the case of chemical landscapes, these images dabble in a tradition that begins in the high art conventions of the sublime landscape but, like those conventions, has the potential to cross the line into the naive and unironic aesthetics of kitsch. On the other hand, as is evident in the section on abstraction where we analyzed the chemical still life, chemistry and its apparatus can inspire commercial artists to reach outside of the representational into artistic traditions that have commanded respect throughout the $20^{\text {th }}$ century.

\section{Notes}

1 Although chemists are photographed and sketched in some other poses, that pose is by far the most dominating public image of chemistry on the Internet and in cliparts according to our previous work (Schummer \& Spector 2007).

2 Pulse feeling was not the same as pulse taking in today's meaning, as long as transportable clocks were unavailable. Instead it consisted of feeling the pressure and rhythm of the pulse.

3 According to Zglinicki (1982, pp. 23-24), the oldest known uroscopy image is in the 12th-century manuscript Regulae urinarum by Maurus and Urso of Salerno.

4 Relief variations of the motif soon appeared on other public places, like the Notre-Dame cathedrals in both Rouen (Zglinicki 1982, p. 133) and Paris (http://education.umn.edu/EdPA/iconics/wander/tour7la.htm, Figure 1-023).

5 Connor 2001, referring to Garrison 1917, pp. 165-6. 
6 For a collection of examples, see Zglinicki 1982, pp. 135-146.

7 On uroscopy in the Dance-of-the-Death tradition, see Zglinicki 1982, pp. 77-96.

8 For a review, see Wilcox \& Whitham 2003; on the related Caduceus symbol (two snake twisted around a rod), which was occasionally used by pharmacists, see Friedlander 1992.

9 This list is compiled from various sources, notably from Holländer 1903, Read 1947, Zglinicki 1982, and Principe \& DeWitt 2002.

10 Teniers knew this painting at least since 1651 when it became part of the collection in Brussels that he supervised (Klinge \& Lüdke 2005, p. 278).

11 Useful internet image sources include the Science \& Society Picture Library and the Ingenious database at the Science Museum London <http://www.scienceandsociety.co.uk $><$ http://www.ingenious.org.uk/ $>$, the Smith Collection at the University of Pennsylvania <http://dewey.library.upenn.edu/sceti/smith/ >, the Wellcome Library <http://medphoto.wellcome.ac.uk>, Wikipedia Commons $<$ http://commons.wikimedia.org>, and Google Images < http://images.google. com $>$.

12 For a documentation of industry in art, see the exhibition catalogue Beneke \& Ottomeier 2002 as well as Frese 2000 and Türk 1997; for early industrial landscape paintings in England, see Klingender 1968, Wagner 1979, and Briggs 1979.

13 Loutherbourg, P. J. de: 1805, The romantic and picturesque scenery of England and Wales, Bowyer, London Plate II (99?).

14 For example see Camille Pissarro's Factory near Pointoise (1873) (Frese, p. 5) and Vincent van Gogh's The Huth Factories at Clichy (1887) (Hughes 1981, p. 326). On impressionist industrial landscapes, see Diers \& Hedinger 2002; on the German Biedermeier tradition of frequently commissioned industrial landscape paintings, see Vorsteher 2002.

15 The following qualitative analyses are based large sets of images that we retrieved from the internet for a quantitative study of the self-image of science (Schummer \& Spector 2007).

16 See the American Chemical Society National Benchmark Survey, July 2000 for a summary of the public's attitudes towards chemistry, chemicals, and chemists.

17 In the introduction to High Techne Rutsky writes that "The aesthetic impulse in modernism continually returns to romantic notions of the aesthetic - or of beauty, at least - as an eternal or spiritual realm, unchanging and whole [...] To this end, it often connects the spiritual and the technological, attempting to impart a sense of wholeness and the eternal to technological forms" (Rutsky 1999, p. 9).

18 For example see Luigi Russolo's Dynamism of an Automobile (1913), Musée National d'Art Moderne, Paris (http://www.futurism.org.uk/russolo/rus_im20.htm)

19 Although recognized as an Neue Sachlichkeit artist Grossberg's images of industrial plants have also been considered to be aligned with surrealism and magical realism (see Hughes 2004, pp. 123-125 and Guenther 1995, pp. 46-48.

20 Sheeler, in particular, made this connection between his art and American industry explicit with his commissioned paintings of the Ford Motor Company.

${ }^{21}$ For example see Renaissance and Baroque period still lifes in Ebert-Schifferer 1999, pp. 115-223. 
22 Of course chemists still use flasks (and sometimes even test-tubes), but like all sciences at this point in the history, chemistry would presumably be much more accurately represented by complex instrumentation.

23 See the virtual art exhibition 'Chemistry in Art' <www.hyle.org/art/cia/ $>$ and Spector \& Schummer 2003.

\section{References}

Abramowicz, J.: 2004, Giorgio Morandi: The Art of Silence, Yale University Press, New Haven.

Becher, H. \& Becher, B: 2002, Industrial landscapes, MIT Press, Cambridge, MA.

Beneke, S. \& Ottomeier, H. (eds.): 2002, Die Zweite Schöpfung: Bilder der industriellen Welt vom 18. Jahrbundert bis in die Gegenwart, Edition Minerva, Wolfratshausen.

Beretta, M.: 2000, 'Chemical Imagery and the Enlightenment of Matter', in: W.R. Shea (ed.), Science and the Visual Image in the Enlightenment, Science History Publications, Canton, MA, pp. 57-88.

Binkley, S.: 2000, 'Kitsch as a Repetitive System: A Problem for the Theory of Taste Hierarchy', Journal of Material Culture, 5, p. 131-152.

Bowden, M.E.: 1997, Chemical Archiever: The Human Face of the Chemical Sciences, Chemical Heritage Foundation, Philadelphia.

Briganti, G. \& Hollander, J.: 1991, William Bailey, Rizzoli, New York.

Briggs, A.: 1979, Iron Bridge to Crystal Palace: Impact and Images of the Industrial Revolution, Thames \& Hudson, London.

Broch, H.: 1969 [1950], 'Notes on the Problem of Kitsch', in: G. Dorfles (ed.), Kitsch: The World of Bad Taste, Universe Books, New York, pp. 49-76.

Brown, K.: 1996, Ink, Paper, Metal, Wood, Chronicle Books, San Francisco.

Burke, E.: 1757, A Philosophical Inquiry into the Origin of Our Ideas of the Sublime and Beautiful, Dodsley, London.

Connor, H.: 2001, 'Medieval uroscopy and its representation on misericords. Part 1: Uroscopy', Clinical Medicine, 1 (6), 507-9.

Constable, J.: 1998 [1821], 'Letter to his friend Archdeacon Fischer', in: M. Gayford \& K. Wright (eds.), The Grove Book of Art Writing, Grove Press, New York, pp. 50-1.

Dalton, J.: 1798, 'Extraordinary facts relating to the vision of colours, with observation', Memoirs of the Literary and Philosophical Society of Manchester, 5, 28-45.

Daniels, S.: 1999, Joseph Wright, Princeton University Press, Princeton.

Diers, M. \& Hedinger, B.: 2002, 'Z.B. (Dampf-)Wolken - Von der Natur der Industrie in Bildern des Impressionismus nebst einer Allegorie', in: Beneke, S. \& Ottomeier, H. (eds.): Die Zweite Schöpfung: Bilder der industriellen Welt vom 18. Jabrbundert bis in die Gegenwart, Edition Minerva, Wolfratshausen, pp. 7279.

Downs, L. B.: 1999, Diego Rivera: The Detroit Industry Murals, W. W. Norton, New York.

Ebert-Schifferer, S: 1999, Still Life: A History, Harry N. Abrams, New York.

Frese, G.: 2000, Dow Chemical Portrayed, Chemical Heritage Foundation, Philadelphia. 
Fried, M.: 2002, Menzel's Realism: Art and Embodiment in Nineteenth-Century Berlin, Yale University Press, New Haven.

Friedlander, W.J.: 1992, The Golden Wand of Medicine: A History of the Caduceus Symbol in Medicine, Greenwood, New York.

Garrison F.H.: 1917, An introduction to the history of medicine, 2nd edn., Saunders, Philadelphia \& London.

Golinksi, J.: 1992, Science as Public Culture: Chemistry and Enlightenment in Britain, 1760-1820, Cambridge University Press, Cambridge.

Grape-Albers, H.: 1977, Spätantike Bilder aus der Welt des Arztes: medizinische Bilderhandschriften der Spätantike und ibre mittelalterliche Überlieferung, Pressler, Wiesbaden.

Greenberg, C.: 1939, 'Avant-Garde and Kitsch', Partisan Review, 6 (5), pp. 34-49.

Greenburg, A.: 2003, The Art of Chemistry, Wiley, Hoboken, NJ.

Guenther, I: 1995, 'Magical Realism, New Objectivity, and the Arts During the Weimar Republic', in: L. P. Zamora \& W. B. Faris (eds.), Magical Realism: Theory, Histroy, Community, Duke University Press, Durham, N.C., pp. 33-74.

Herbert, R.L.: 1997, 'The Arrival of the Machine: Modernist Art in Europe 1910-25', Social Research, 64, 1273-1305.

Holländer, E.: 1903, Die Medizin in der klassischen Malerei, Enke, Stuttgart $4^{\text {th }}$ edn. 1950).

Holländer, E.: 1905, Die Karikatur und Satire in der Medizin, Enke, Stuttgart (2nd edn. 1921).

Holländer, E.: 1912, Plastik und Medizin, Enke, Stuttgart.

Hughes, T. P.: Human Built World, University of Chicago Press, Chicago.

Janson, H.W.: 1952, Apes and Ape Lore in the Middle Ages and Renaissance, Warburg Institute, London (Studies of the Warburg Institute, no. 20).

Kant, I.: 1790, Kritik der Urteilskraft, Lagarde, Berlin.

Klinge, M. \& Lüdke, D. (eds.): 2005, David Teniers der Jüngere, 1610-1690: Alltag und Vergnügen in Flandern, Staatliche Kunsthalle, Karlsruhe.

Klingender, F. D.: 1968, Art and the Industrial Revolution, Augustus M. Kelley, New York.

Knight, D.: 1996, 'Illustrating Chemistry', in: B.S. Baigrie (ed.), Picturing Knowledge: Historical and Philosophical Problems Concerning the Use of Art and Science, Univ. of Toronto Press, Toronto.

Knight, D.: 2003, 'Exalting Understanding without Depressing Imagination: Depicting Chemical Process', Hyle: International Journal for Philosophy of Chemistry, 9, 171-89.

Koerner, J. L.: 1990, Casper David Friedrich and the Subject of Landscape, Yale University Press, Hartford, CT.

Kulka, T.: 1996, Kitsch and Art, Pennsylvania State UP, University Park.

Lanchner, C: 1998, Fernand Leger, The Museum of Modern Art, New York, NY.

Light, E.M.: 1995, Picturing Modernism: Maboly-Nagy and Photography in Weimar Germany, MIT Press, Cambridge, MA.

Linden, S.J.: 1996, Darke hierogliphicks. Alchemy in English Literature from Chancer to the Restoration, University Press of Kentucky, Lexington.

Lindgren, U.: 1992, Die Artes liberales in Antike und Mittelalter: bildungs- und wissenschaftsgeschichtliche Entwicklungslinien, Institut für Geschichte der Naturwissenschaften, München.

Lugon, O.: 2003, 'The Machine Between Cult Object and Merchandise', in: E. de Chassey (ed.), American Art: 1908-1947 from Winslow Homer to Jackson Pollock, Abrams, New York. 
MacKinney, Loren C.: 1965, Medical illustrations in medieval manuscripts, Univ. of California Press, Berkeley.

Metzl, J.M. \& Howell, J.D.: 2004, 'Making History: Lessons from the Great Moments Series of Pharmaceutical Advertisements', Academic Medicine, 79 (11), 1027 32.

Michalski, S.: 2003, New Objectivity: Painting, Graphic Art and Photography in Weimar Germany 1919-1933, Taschen, Kohn.

Mitchell, W.J.T. (ed.): 2002, Landscape and Power, 2nd edn., Univ. of Chicago Press, Chicago.

Nicoldon, B.: 1968, Joseph Wright of Derby, Routledge, London.

Obrist, B.: 2003, 'Visualization in Medieval Alchemy', Hyle: International Journal for Philosophy of Chemistry, 9, 131-70.

Principe, L.M. \& DeWitt, L.: 2002, Transmutations: Alchemy in Art, Chemical Heritage Foundation, Philadelphia.

Read, J.: 1947: The Alchemist: In Life, Literature and Art, Thomas Nelson, London.

Robinson, C. \& Herschman, J.: 1987, Architecture Transformed: A History of the Photography of Buildings from 1839 to the Present, MIT Press, Cambridge.

Rodner, W.S.: 1997, J.M.W. Turner: Romantic Painter of the Industrial Revolution, University of California Press, Berkeley.

Ross, A.: 1989, No Respect: Intellectuals and Popular Culture, Routledge, New York.

Rutsky, R.L.: 1999, High Techne: Art and Technology from the Machine Aesthetic to the Posthuman, Univ. of Minnesota Press, Minneapolis.

Schadewaldt, H.; Binet, L.; Maillant, C. \& Veith, I.: 1967, Kunst und Medizin, DuMont Schauberg, Köln.

Schummer. J.: 2006, 'Historical Roots of the Mad Scientist: Chemists in 19th-century Literature', Ambix, 53, 99-127.

Schummer, J. \& Spector, T.I.: 2007, 'Popular Images versus Self-Images of Science: Visual Representations of Science in Clipart Cartoons and Internet Photographs', in: B. Hüppauf \& P. Weingart (eds.), Science Images and Popular Images of Science, London-New York: Routledge, 2007, pp. 69-95 (in print).

Snyder, J.: 2002, 'Territorial Photography', in: W.J.T. Mitchell (ed.): 2002, Landscape and Power, 2nd edn., Univ. of Chicago Press, Chicago, pp. 175-201.

Solomon, R.C.: 1991, 'On Kitsch and Sentimentality', The Journal of Aesthetics and Art Criticism, 49, 1-14.

Spector, T.I. \& Schummer, J.: 2003, 'Chemistry in Art: Introduction to the Virtual Art Exhibition', Hyle: International Journal for Philosophy of Chemistry, 9, 225-232.

Stafford, B.M.: 1996, Good Looking, MIT Press, Cambridge, MA.

Troyan, C. \& Hirshler, E.E.: 1987, Charles Sheeler: Paintings and Drawings, Little \& Brown, Boston.

Türk, K. (ed.): 1997, Arbeit und Industrie in der bildenden Kunst, Steiner, Stuttgart.

Vorsteher, D.: 2002, 'Das Industriebild als Auftrag zwischen Vormärz und Gründerzeit', in: Beneke, S. \& Ottomeier, H. (eds.): Die Zweite Schöpfung: Bilder der industriellen Welt vom 18. Jabrbundert bis in die Gegenwart, Edition Minerva, Wolfratshausen, pp. 66-71.

Wagner, M.: 1979, Die Industrielandschaft in der englischen Malerei und Graphik, 1770-1830, Lang, Frankfurt.

White, W.I.: 1991, 'A New Look at the Role of Urinalysis in the History of Diagnostic Medicine', Clinical Chemistry, 37 (1), 119-125.

Wilcox, R.A. \& Whitham, E.M.: 2003, 'The Symbol of Modern Medicine: Why One Snake Is More Than Two', Annals of Internal Medicine, 138, 673-677. 
Williamson, K.L.: 2003, Macroscale and Microscale Organic Experiments, $4^{\text {th }}$ edn., Houghton Mifflin, Boston.

Zglinicki, F.v.: 1982, Die Uroskopie in der bildenden Kunst: eine kunst- und medizinhistorische Untersuchung über die Harnschau, GIT-Verlag, Darmstadt.

Zotter, H.: 1980, Antike Medizin: die medizinische Sammelhandschrift Cod. Vindobonensis 93 in lateinischer und deutscher Sprache, Akadademische Druck- u. Verlagsanstalt, Graz.

Joachim Schummer:

Department of Philosophy, University of Darmstadt, Schloss, 64283

Darmstadt, Germany;js@byle.org

Tami I. Spector:

Department of Chemistry, University of San Francisco, 2130 Fulton St., San Francisco, CA 94117-1080,USA; spector@usfca.edu 